\title{
A Systematic Study of Nitrated Indenoisoquinolines Reveals a Potent Topoisomerase I Inhibitor
}

\author{
Andrew Morrell ${ }^{\dagger}$, Smitha Antony $\ddagger$, Glenda Kohlhagen $\ddagger$, Yves Pommier ${ }^{\ddagger}$, and Mark \\ Cushman ${ }^{*}, \dagger$ \\ Department of Medicinal Chemistry and Molecular Pharmacology, School of Pharmacy and \\ Pharmaceutical Sciences, and the Purdue Cancer Center, Purdue University, West Lafayette, IN \\ 47907, Laboratory of Molecular Pharmacology, Center for Cancer Research, National Cancer \\ Institute, Bethesda, MD 20892-4255
}

\begin{abstract}
The biological activity of indenoisoquinoline topoisomerase I inhibitors is significantly enhanced by nitration of the isoquinoline ring. In the present study, nitrated analogues were synthesized with the indenone ring substituted with methoxy groups to further explore a previously identified structureactivity relationship between the nitrated isoquinoline ring and a methylenedioxy-substituted indenone ring. The results indicate that a single methoxy group at the 9-position of an indenoisoquinoline affords superior biological activity. Hypothetical binding models have been developed in order to rationalize these results and they indicate that $\pi$-stacking between the indenoisoquinolines and DNA base pairs, as visualized by electrostatic complementarity, is important for the intercalation and biological activity of the indenoisoquinoline analogues. Collectively, the analysis of methoxy groups on the indenone ring also illustrates a strict steric requirement for substituents extending towards the non-scissile DNA backbone and emphasizes a need for planarity to afford potent biological activity.
\end{abstract}

\section{Introduction}

In 1998, the discovery of an indenoisoquinoline topoisomerase I (Top1) inhibitor (compound 1, Figure 1) was reported. ${ }^{1}$ This indenoisoquinoline is representative of a novel class of cytotoxic molecules that exert their biological effects by intercalating between the DNA base pairs at Top1's cleavage site. ${ }^{1-3}$ This mechanism of action is identical to the natural product camptothecin (2) and its clinically useful derivatives topotecan and irinotecan. ${ }^{4-9}$ Recent crystal structures elegantly demonstrate the net effect of drug intercalation at Top1's cleavage site, indicating an elongation of the DNA such that re-ligation of the DNA backbone and release of competent enzyme cannot occur. ${ }^{10-13}$ This mechanism of action categorizes both the indenoisoquinolines and camptothecins as Top1 "poisons" and not Top1 "suppressors", which inhibit Top1's ability to cleave the phosphodiester backbone of supercoiled DNA. ${ }^{14}$

Although indenoisoquinoline 1 was demonstrated to inhibit Top1, it suffered from intrinsically low biological activity. ${ }^{1}$ However, compound 1 constituted a new class of Top 1 inhibitors and efforts were made to improve the biological activity of the indenoisoquinolines by manipulating their substitution pattern. ${ }^{12,15-22}$ These synthetic efforts have focused on exploring the substitution pattern of the lactam nitrogen with a wide variety of carbon and

\footnotetext{
*To whom correspondence should be addressed. Tel: 765-494-1465. Fax: 765-494-6790. Email: cushman@pharmacy.purdue.edu.

$\dagger$ Purdue University

\$National Cancer Institute, NIH.
} 
heteroatom substituents, and studying the effect of the methylenedioxy ring as it relates to biological activity. ${ }^{20}$ During the course of this work, several advances have occurred that facilitate structure-based drug design of Top1 inhibitors. First, crystal structures of intercalative inhibitors such as topotecan, camptothecin, an indolocarbazole, and two indenoisoquinolines have been solved in complex with DNA and Top $1 .^{10-12}$ Second, the necessity of indenoisoquinoline aromatic substituents such as di(methoxy) and methylenedioxy was previously dictated by the need for electron-donating groups in a suitable position to activate a thionyl chloride-induced oxidation/Friedel-Crafts acylation transformation, ${ }^{23}$ but a slight modification utilizing aluminum chloride now provides access to a wide range of indenone substituents that were previously unattainable. ${ }^{24}$

Examination of recently published crystal structures composed of an indenoisoquinoline, DNA, and Top1 suggests that in addition to a critical hydrogen bond between the 11-position carbonyl oxygen and the guanidine motif of Arg364, a large percentage of the solventaccessible surface of an indenoisoquinoline's aromatic rings is involved in $\pi$-stacking interactions with the DNA bases above and below intercalation. ${ }^{11-13}$ This appears to be a general feature of intercalative Top 1 inhibitors and it seems reasonable to assume that inhibitor binding is controlled in large part by favorable $\pi$-stacking interactions between the DNA bases and the aromatic rings of the drug molecule. ${ }^{13}$ In fact, this hypothesis has recently been studied in our laboratory with computational evidence supporting $\pi$-stacking interactions as a predominant stabilizing factor for both camptothecins 25,26 and the indenoisoquinolines. ${ }^{27}$ Thus, it would appear that a rational method to improve Top1 inhibition would be to increase a drug molecule's ability to $\pi$-stack with neighboring DNA base pairs. A preliminary effort related to this concept was reported by our laboratory involving the preparation of nitrated indenoisoquinolines and discovering their ability to improve Top1 inhibition relative to nonnitrated compounds. ${ }^{24}$ Exceptional activity was observed when a nitro group was incorporated on the isoquinoline ring in conjunction with a methylenedioxy group fused to the indenone ring (illustrated by compounds 3-5). ${ }^{24}$ However, reduction of the nitro group to the corresponding aniline 6 resulted in a 100-fold loss in cytotoxicity and completely negated Top1 inhibition. ${ }^{24}$ A similar result was reported for a related series of Top1 inhibitors during the conclusion of our initial studies, indicating the generality of enhanced Top1 inhibition by the methylenedioxy ring and nitro group and necessitating further exploration of this effect. ${ }^{28}$

The present investigation was undertaken to further explore the improvement in biological activity previously reported for indenoisoquinolines possessing a nitrated isoquinoline ring and a methylenedioxy-substituted indenone ring. To accomplish this task, the nitro substituent on the isoquinoline ring was held constant and modifications in the form of methoxy groups were systematically made to the indenone ring. Collectively, the design provided a method to probe the effects of increasing the number of electron-rich methoxy substituents, positional effects, and steric requirements for indenone ring substituents. Furthermore, the roles of the methylenedioxy ring (and methoxy groups), the nitro group, and their relation to biological activity has been identified utilizing structural analogies to camptothecin and molecular modeling.

\section{Chemistry}

Indenoisoquinolines 24-38 were synthesized following the route described in Scheme 1. Condensation of Schiff bases 8-15 with 4-nitrohomophthalic anhydride (7) ${ }^{29}$ provided carboxylic acids 16-23 in good yield. Five of the carboxylic acids were then oxidatively cyclized $^{23}$ to provide indenoisoquinolines $\mathbf{2 4}-\mathbf{2 8}$ by treatment with thionyl chloride and aluminum chloride according to the conditions provided in Scheme 1. 
Unexpectedly, carboxylic acids $\mathbf{1 6}$ and $\mathbf{2 0}$ underwent mono-demethylation upon subjection to the reaction conditions, although cyclization and oxidation did occur. ${ }^{30}$ Presumably, demethylation occurred at position $\mathrm{R}_{4}$ through the coordination of aluminum chloride with the carbonyl oxygen at the 11-position of the aromatic ring. ${ }^{31}$ However, the exact position of demethylation has not been confirmed experimentally. Ultimately, compound 16 was successfully elaborated as reported in Scheme 2 and compound $\mathbf{2 0}$ was eliminated from further synthetic efforts as a result of molecular modeling studies of the desired analogue in ternary complex with DNA and Top1. Unfortunately, the elaboration of carboxylic acid $\mathbf{2 2}$ to the corresponding indenoisoquinoline also proved to be problematic, with reaction conditions providing a mixture of indenoisoquinoline regioisomers that proved impossible to separate. Multiple reactions conditions were attempted in an effort to select for the formation of one major regioisomer, but to no avail. Subsequently, the corresponding series of 8-position methoxy group analogues were eliminated from the current study. The lactam side chains of indenoisoquinolines 24-28 were then elaborated from propylhalide to propylazide by treatment with $\mathrm{NaN}_{3}$ in DMSO (providing compounds 29-33) and reduced with triethyl phosphite to provide indenoisoquinolines $\mathbf{3 4 - 3 8}$, which were isolated as their hydrochloride salts.

As previously mentioned, carboxylic acid $\mathbf{1 6}$ was elaborated to the corresponding tri(methoxy)substituted indenoisoquinoline series as outlined in Scheme 2. Friedel-Crafts ring closure was accomplished utilizing $\mathrm{P}_{2} \mathrm{O}_{5}$ in refluxing chloroform to provide dihydroindenoisoquinoline 39. 23 Previously, we discovered that nitrated dihydroindenoisoquinolines were highly cytotoxic molecules but were poor Top1 inhibitors. ${ }^{24}$ Presumably, these molecules are exerting their biological effects in a prodrug manner as previously described. ${ }^{32,33}$ Continuing this study, compound $\mathbf{1 8}$ was dehydratively cyclized to provide dihydroindenoisoquinoline 40. Compounds $\mathbf{3 9}$ and $\mathbf{4 0}$ were oxidatively transformed into the corresponding azidosubstituted indenoisoquinolines $\mathbf{4 1}$ and $\mathbf{3 0}$ by treatment with sodium azide in DMSO, a previously reported oxidation that is still not yet fully understood. ${ }^{24}$ Finally, reduction of the azido group present in compounds $\mathbf{4 1}$ and $\mathbf{3 0}$ proceeded smoothly to provide compounds $\mathbf{4 2}$ and $\mathbf{3 5}$ upon isolation as their hydrochloride salts.

\section{Biological Results and Discussion}

The indenoisoquinolines were examined for antiproliferative activity against the human cancer cell lines in the National Cancer Institute screen, in which the activity of each compound was evaluated with approximately 55 different cancer cell lines of diverse tumor origins. The GI50 values obtained with selected cell lines, along with the mean graph midpoint (MGM) values, are summarized in Table 1. The MGM is based on a calculation of the average GI50 for all of the cell lines tested (approximately 55) in which GI50 values below and above the test range $\left(10^{-8}\right.$ to $10^{-4}$ molar $)$ are taken as the minimum $\left(10^{-8}\right.$ molar $)$ and maximum $\left(10^{-4}\right.$ molar $)$ drug concentrations used in the screening test. For comparison purposes, the activities of the previously reported lead compound $\mathbf{1}^{1}$, camptothecin (2), and compounds $3-6^{24}$ are also included in the table. The relative potencies of the compounds in the production of topoisomerase I-mediated DNA cleavage are also listed in the table. These results were expressed semiquantitatively as follows: 0 : no detectable activity; + : weak activity; ++ : similar activity as compound $\mathbf{1} ;+++$ and ++++: greater activity than compound $\mathbf{1} ;++++$ : similar activity as $1 \mu \mathrm{M}$ camptothecin; +++++: greater activity than $1 \mu \mathrm{M}$ camptothecin.

The results in Table I indicate that a methoxy-substituted indenone ring has a pronounced effect on the biological activity of nitrated indenoisoquinoline analogues. In general, if one defines an "active" analogue to have an MGM of less than $1 \mu \mathrm{M}$ or a Top1 inhibition of at least +++, then only one analogue with three methoxy groups on the indenone ring, compound 39 (MGM: $0.209 \mu \mathrm{M}$, Top1: ++), satisfies the criteria to be "active" due to its MGM. Furthermore, since compound $\mathbf{3 9}$ is a weak Top1 inhibitor, it could be argued that its cytotoxicity may not be a 
direct consequence of Top1 inhibition. Examination of the tri(methoxy) series of compounds was made even more interesting by the fact that compounds $\mathbf{3 4}$ and $\mathbf{4 2}$ possessed a propylamino-substituted lactam nitrogen. In the past, this functionality has been demonstrated to improve the biological activity of the indenoisoquinolines through potential interactions with DNA base pairs or Top 1 in the ternary complex. ${ }^{19,20}$ Seemingly, three methoxy groups on the indenone ring of the indenoisoquinolines causes such poor activity that it cannot be resurrected by incorporating an activating moiety elsewhere in the inhibitor. This result was also disappointing since the tri(methoxy) series of compounds $(\mathbf{2 4}, \mathbf{2 9}, \mathbf{3 4}, \mathbf{4 1}$, and $\mathbf{4 2}$ ) provided the first nitrated indenoisoquinolines to not display enhanced biological activity similar to compounds 3-5.

The preparation and evaluation of di(methoxy)-substituted analogues did not fair much better than the tri(methoxy) series. Compounds such as $\mathbf{2 5 , 2 6 , 3 0 , 3 1 , 3 5}$, and $\mathbf{3 6}$ were also found to be less active than compounds $3-5$. Compounds 35 and $\mathbf{3 6}$ barely met the criteria for an "active" compound in this series. This result was initially surprising due to the envisioned similarities (stereoelectronics and hydrogen-bond capabilities) between a methylenedioxy-substituted indenone ring (such as that present in 3-5) and the corresponding di(methoxy)-substituted analogues $(\mathbf{2 5}, \mathbf{3 0}$, and 35). Furthermore, predicted steric interactions resulting from the replacement of a conformationally restricted methylenedioxy ring for the di(methoxy) substituents were expected to have a small effect on biological activity, especially since potent analogues had been made with a di(methoxy)-substituted isoquinoline ring. A 10-fold loss in cytotoxicity and a 50\% reduction in Top1 inhibition between compounds $\mathbf{5}$ and $\mathbf{3 5}$ were not initially expected.

In the course of this study, dihydroindenoisoquinolines $\mathbf{3 9}$ and $\mathbf{4 0}$ were prepared and their biological activities were evaluated. From a structural perspective, dihydroindenoisoquinolines are generally not potent Top 1 inhibitors due to their perceived inability to intercalate into the ternary complex. $1,12,17,24,33$ Alternatively, these molecules are envisioned as serving as prodrugs where a two-electron oxidation to form the dehydrogenated indenoisoquinoline is proposed to occur. ${ }^{32}$ A previously synthesized dihydroindenoisoquinoline with a 3-position nitro group and a methylenedioxy ring fused to the 8- and 9-positions demonstrated potent cytotoxicity but diminished Top1 inhibition. Interestingly, di(methoxy)-substituted analogue 40 (MGM: $10.7 \mu \mathrm{M}$, Top1: 0) did not display similar cytotoxicity to the methylenedioxy variant, but instead continued the present trend of inactivity for compounds possessing multiple methoxy groups on the indenone ring. Conversely, dihydroindenoisoquinoline 39, with methoxy groups in the 8-, 9-, and 10-positions, displayed potent cytotoxicity (MGM: 0.209 $\mu \mathrm{M})$ and modest Top1 inhibition (++), a result similar to the activity of previously reported nitrated dihydroindenoisoquinolines. ${ }^{24}$ However, this cytotoxicity must be independent of any prodrug activity in light of the modest potency of the tri(methoxy)-substituted indenoisoquinolines $(\mathbf{2 4}, \mathbf{2 9}, \mathbf{3 4}, \mathbf{4 1}$, and $\mathbf{4 2})$ towards Top1 inhibition and cytotoxicity.

Previously examined structure-activity relationships for camptothecin derivatives and examination of recently published crystal structures provided essential clues to the reason why tri(methoxy)- and di(methoxy)-substituted indenoisoquinolines in this study had such poor biological activity. ${ }^{34,35}$ 10,11-Methylenedioxy-substituted camptothecin (atom numbering shown in Figure 1) has been demonstrated to exert potent biological activity, however, replacement of the methylenedioxy ring with di(methoxy) groups resulted in complete loss of biological activity. ${ }^{34}$ This result was attributed to steric interactions between the 10- and 11position methoxy groups, decreasing the number of planar conformations the camptothecin derivative can adopt and concomitantly increasing steric interactions with the DNA base pairs at the site of intercalation. ${ }^{35} \mathrm{X}$-ray crystallography has demonstrated that the 10 - and 11positions of the camptothecins occupy a similar space as the 8- and 9-positions of the indenoisoquinolines (Figure 2). ${ }^{11}$ Thus, conclusions similar to those drawn for the di 
(methoxy)-substituted camptothecin derivative can be drawn for the indenoisoquinolines. Deleterious steric interactions between methoxy groups and the DNA must be contributing to the currently observed loss in biological activity of tri(methoxy)- and di(methoxy)-substituted indenoisoquinoline analogues. Steric repulsion between the methoxy groups would force them out of the plane of the indenone ring and result in deleterious encounters with the DNA base pairs at the site of intercalation, a result confirmed by hypothetical binding models developed for compounds 34 and $\mathbf{3 5}$. In addition, the space on the non-cleaved strand of DNA (right side of Figure 2) is more constrained than on the cleaved side of DNA (left side of Figure 2). That may explain why the overlap between camptothecin and the indenoisoquinoline is better on the right side. The greater steric bulk of the di(methoxy)-substituted indenoisoquinolines evidently compromises their ability to fit into the more constrained side of the DNA, next to the non-cleaved strand.

Interestingly, potent indenoisoquinoline derivatives have been prepared with a di(methoxy)substituted isoquinoline ring. ${ }^{12,15-19,21,22}$ However, X-ray crystallography has confirmed that the isoquinoline ring is intercalated into the scissile DNA strand, whereas the indenone ring is intercalated into the non-scissile DNA strand. ${ }^{11,12}$ The scissile DNA strand may be more forgiving towards steric interaction since its cleavage by Top 1 can afford release of strain and increased space for substituents on the intercalator relative to the non-scissile strand. The current results clearly demonstrate that the non-scissile strand is less accommodating to steric interactions between an intercalative inhibitor and the DNA base pairs and confirms the previously observed structure-activity relationships of the camptothecin derivatives. Furthermore, the result advises the incorporation of substituents on the indenone ring that are capable of achieving planar conformations for potent biological activity.

Realizing the spatial limitations for substituents on the indenone ring, the methoxy analogue series was continued with the incorporation of a single methoxy group at either the 7- or 9position of the indenoisoquinolines (compounds $27, \mathbf{2 8}, \mathbf{3 2}, \mathbf{3 3}, \mathbf{3 7}$, and 38). Immediately, the continuation of the study was validated with compound 27 (MGM: $0.178 \mu \mathrm{M}$, Top1: ++++) showing excellent biological activity only 2 -fold less cytotoxic than $\mathbf{5}$ and equal in Top1 inhibition to both camptothecin (2) and analogue 5. Furthermore, azido-substituted compound 32 showed comparable biological activity (MGM: $0.198 \mu \mathrm{M}$, Top1: +++) to compounds 27 and 5. Evaluation of analogue 37 (MGM: $0.027 \mu \mathrm{M}$, Top1: +++++) was even more gratifying since it was approximately 2 -fold more cytotoxic than camptothecin and a better Top 1 inhibitor. At the conclusion of this study, compound $\mathbf{3 7}$ represented the most potent indenoisoquinoline Top1 inhibitor synthesized to date. Interestingly, the 7-position methoxy-substituted analogues $(\mathbf{2 8}, \mathbf{3 3}$, and 38) did not show similar activity to the 9-position analogues $(\mathbf{2 7}, \mathbf{3 2}$, and $\mathbf{3 7})$ and were lacking the previously observed activity enhancement from possession of a nitrated isoquinoline ring. This is rationalized to be the result of deleterious steric interactions with the lactam side chain, limiting the number of planar conformations that can be adopted by the 7position methoxy group (relative to the 9-postion) and increasing steric repulsion with the DNA base pairs of the non-scissile strand. However, the 7-position analogues did show marked improvement over the tri(methoxy)- and di(methoxy)-substituted derivatives with compound 38 (MGM: $1.41 \mu \mathrm{M}$, Top1: ++++) showing excellent Top1 inhibition comparable to that of camptothecin (2). This result emphasized that although the indenone ring tolerated a methoxy substituent at the 7-position, the optimal place to incorporate this substituent is in the 9-position of the indenoisoquinolines and only the 9-position analogues in this study displayed similar enhanced activity to that observed in our previous study exemplified by compounds 3-5.

The DNA cleavage patterns produced by camptothecin ( 2 , lane 3 of each gel), the indenoisoquinoline MJ-III-65 (NSC 706743, compound 43, lane 4 of each gel), and compounds $\mathbf{5}^{24}, \mathbf{2 7}, \mathbf{3 2}, \mathbf{3 7}$, and $\mathbf{3 8}$ are displayed in Figure 3. The following points are apparent from inspection of the gels: 1) The potencies of the indenoisoquinolines as Top1 inhibitors are 
reflected in the intensities of the DNA cleavage bands. The bands produced by compound $\mathbf{3 2}$ (Top $1:+++)$ are slightly weaker in comparison with the other analogues and camptothecin. 2) Top1 inhibitors can be classified as Top1 suppressors, which inhibit DNA cleavage, and Top1 poisons, which inhibit the re-ligation reaction after DNA cleavage. Many of the Top1-mediated DNA cleavages are trapped at lower compound concentrations and suppressed at higher concentrations, and therefore the indenoisoquinolines act as Top1 poisons at lower concentrations and Top1 suppressors at higher concentrations. The suppression could result from binding of the drug to the DNA rendering it a poorer enzyme substrate at high drug concentration, or from a direct effect on the enzyme to suppress its ability to cleave DNA. Although all of the analogues presented in Figure 3 demonstrated this effect, compounds 5 (Top1: ++++) and $\mathbf{3 7}$ (Top1: +++++) are especially noteworthy given the strong band intensities in lanes 5-6 for 5 and lanes 5-7 for 37. Increased concentrations of 5 (lanes 7 and 8 ) and 37 (lane 8 ) resulted in a striking decrease in band intensity at cleavage sites 44,70 , and 92.3) There are differences in the cleavage pattern of camptothecin vs. the indenoisoquinolines. For example, the cleavage at base pair 44 seen with the indenoisoquinolines is absent with camptothecin. This difference may indicate that the indenoisoquinolines might display antitumor spectra different from camptothecin or its clinically useful derivatives irinotecan and topotecan.

In an attempt to understand the contributions towards biological activity of the 3-position nitro group and the 9-position methoxy group (as well as the 8,9-methylenedioxy ring), a hypothetical binding model was developed using compound $\mathbf{3 7}$ and a previously reported crystal structure ${ }^{11}$ of an indenoisoquinoline in ternary complex with DNA and Top1 (Figure 4). Compound $\mathbf{3 7}$ is capable of making several hydrogen-bonding contacts to enhance the stabilization of the ternary complex, illustrated as yellow lines in Figure 4. One oxygen atom of the nitro group is shown to participate in hydrogen bonding with the amide protons of the Asn722 side chain (heavy atom distance of $2.37 \AA$ ), thereby providing a potential role for the increased biological activity of nitrated indenoisoquinolines. The amino group on the lactam side chain of $\mathbf{3 7}$ is suitably positioned in the hypothetical model for hydrogen bonding with an oxygen atom of thymine (heavy atom distance of $2.58 \AA$ ), which would explain the increased biological activity seen the compound $\mathbf{3 7}$ in comparison with $\mathbf{2 7}$ and $\mathbf{3 2}$. Furthermore, a hydrogen bond is proposed between the 11-position carbonyl oxygen of $\mathbf{3 7}$ and the guanidine protons of Arg364 (heavy atom distance of $2.65 \AA$ ). However, there were no observed contacts with any amino acid residue and the methoxy group at the 9-position. In order to determine if indirect contacts involving bridging water molecules could account for the observed difference in biological activity between $\mathbf{3 7}$ and $\mathbf{3 8}$, the higher resolution crystal structure reported for topotecan (which indicates the presence of water molecules at the intercalation site) was further utilized for modeling studies (see Supporting Information). ${ }^{10}$ The results of these modeling studies indicated that the only difference between the 7- and 9-position methoxy groups in compounds $\mathbf{3 7}$ and $\mathbf{3 8}$ was a single bridging hydrogen-bond between a water molecule and the 9-position methoxy group, ultimately terminating in a contact with Lys374 and a phosphate group of the DNA backbone. One would not expect this to be sufficient enough to account for the differences in Top1 inhibition between compounds 27 and 28, 32 and 33, and $\mathbf{3 7}$ and 38, all of which should display similar contacts with their respective methoxy groups. Thus, hydrogen-bonding interactions alone do not appear to fully rationalize the biological activities of these molecules.

Previous molecular modeling studies have indicated that $\pi$-stacking plays a definitive role in the binding of indenoisoquinolines in the ternary complex. ${ }^{27}$ Utilizing electrostatic potential surfaces to visualize the charge complementarity contribution to $\pi$-stacking, a hypothetical binding model has been developed that emphasizes a role for the 3-position nitro group and the 9-position methoxy group (or methylenedioxy group) in addition to their hydrogen-bonding capabilities (Figures 5 and 6). The models illustrated in Figures 5 and 6 were constructed from 
the energy-minimized complexes of $\mathbf{5}$ and $\mathbf{3 7}$ in ternary complex with DNA and Top1. Replacement of the aminopropyl lactam side chains present in compounds $\mathbf{5}$ and $\mathbf{3 7}$ with a methyl group was performed in order to improve the overall contrast between areas of net negative and positive charge in the $\pi$-stacking model. This simplification seemed justified since the present emphasis is on the aromatic ring substituents and not the lactam side chains, which would be expected to have similar interactions for both compounds in the ternary complex. Lastly, the deoxyribose sugars of the DNA base pairs at the site of intercalation were replaced with a methyl groups, a modification previously demonstrated to still allow accurate calculations predicting the binding of an indenoisoquinoline. ${ }^{27}$ Electrostatic potential surfaces [globally scaled to a range of $-25 \mathrm{kcal} / \mathrm{mol}$ (red) to $+25 \mathrm{kcal} / \mathrm{mol}$ (blue)] were then generated in Sybyl ${ }^{\circledR}$ using MMFF94 charges for the DNA base pairs (illustrated as lines) and $\mathbf{5}$ and $\mathbf{3 7}$ (both shown as opaque). Each figure possesses orientations to allow the viewing of charge complementarity from the -1 base pair (left) and +1 base pair (right).

In Figures 5 and 6, three general areas are proposed to account for the overall improvement in biological activity seen for nitrated indenoisoquinolines. First, the electron-rich oxygen atoms of the nitro groups present in both compounds complement the electron deficient outer edges of the scissile strand DNA base pair (left edge of both orientations). Second, the electronwithdrawing nature of the nitro group results in a relatively electron-deficient aromatic ring system of the indenoisoquinolines (compared to the DNA base pairs). This deficiency results in good electrostatic complementarity of both $\mathbf{5}$ and $\mathbf{3 7}$ with the DNA base pairs, contributing to the stabilization of the complex from $\pi$-stacking interactions. Furthermore, this rationale explains the substantial loss in activity from the reduction of the 3-position nitro group to the corresponding aniline (compound 6). Thus, charge complementarity (in conjunction with hydrogen-bonding to Asn722, Figure 3) appears to rationalize the enhanced biological activity of indenoisoquinolines that possess a nitro substituent at the 3-position.

Figures 5 and 6 also provide evidence of charge complementarity of the methoxy group at the 9-postion in compound $\mathbf{3 7}$ and the methylenedioxy group fused to the 8- and 9-positions in compound 5 with the DNA base pairs. The electron-rich, 9-position oxygen atoms in both 5 and $\mathbf{3 7}$ complement the electrostatic potential of the outer edges of the non-scissile DNA base pairs (right edge of both orientations). Furthermore, the slightly improved biological activity of $\mathbf{3 7}$ relative to $\mathbf{5}$ may be related to the observed increase in electrostatic potential of the 9position methoxy group relative to the 8- and 9-position methylenedioxy ring. Thus, Figures 5 and 6 provide a model that suggests electronegative aromatic substituents and an electropositive $\pi$-system provide charge complementarity with the adjacent DNA base pairs, thereby stabilizing the ternary cleavage complex.

In summary, a systematic study of nitrated indenoisoquinolines has revealed a potent Top1 inhibitor with a single methoxy group at the 9-position. The study highlights the deleterious effects of steric interactions between substituents extending towards the non-scissile DNA strand and emphasizes the need for substituents to adopt planar conformations. Furthermore, the structure-activity relationships derived for methoxy-substituted indenoisoquinolines are consistent with the camptothecin class of Top1 inhibitors, suggesting that hypothetical models derived for one molecular class may be applicable to other classes of intercalative Top1 inhibitors (such as indolocarbazoles and lamellarins). Furthermore, hypothetical models indicate that charge complementarity/ $\pi$-stacking and hydrogen-bonding capabilities are responsible for the enhanced biological activity of nitro- and methoxy-/methylenedioxysubstituted indenoisoquinolines. 


\section{Experimental Section}

Melting points were determined using capillary tubes with a Mel-Temp apparatus and are uncorrected. Infrared spectra were obtained using $\mathrm{CHCl}_{3}$ as the solvent unless otherwise specified. The proton nuclear magnetic resonance $\left({ }^{1} \mathrm{H}\right.$ NMR) spectra were recorded using an ARX300 300 MHz Bruker NMR spectrometer. IR spectra were recorded using a Perkin-Elmer 1600 series FTIR spectrometer. Combustion microanalyses were performed at the Purdue University Microanalysis Laboratory and the reported values were within $0.4 \%$ of the calculated values. Analytical thin-layer chromatography was carried out on Baker-flex silica gel IB2-F plates and compounds were visualized with short wavelength UV light. Silica gel flash chromatography was performed using $230-400$ mesh silica gel.

\section{3,4,5-Trimethoxybenzylidene-(3-bromo-1-propylamine) (8)}

The hydrobromide salt of 3-bromopropylamine $(3.682 \mathrm{~g}, 16.82 \mathrm{mmol})$ was treated with triethylamine $(3.2 \mathrm{~mL})$ in $\mathrm{CHCl}_{3}(70 \mathrm{~mL})$ and the mixture was allowed to stir at room temperature for $5 \mathrm{~min}$. 3,4,5-Trimethoxybenzaldehyde $(3.000 \mathrm{~g}, 15.29 \mathrm{mmol})$ and magnesium sulfate $(5.000 \mathrm{~g})$ were added and the solution was stirred at room temperature for $16 \mathrm{~h}$. The solution was filtered and the filter pad was washed with $\mathrm{CHCl}_{3}(100 \mathrm{~mL})$. The filtrate was washed with water $(3 \times 25 \mathrm{~mL})$ and sat aq $\mathrm{NaCl}(25 \mathrm{~mL})$. The organic layer was dried over sodium sulfate, filtered, and concentrated to provide a viscous yellow oil $(4.835 \mathrm{~g}, 100 \%)$. IR (film) $2939,1645,1585,1504,1459,1418,1329,1232,1127$, and $1005 \mathrm{~cm}^{-1} ;{ }^{1} \mathrm{H}$ NMR $\left(\mathrm{CDCl}_{3}\right) \delta 8.22$ (s, $\left.1 \mathrm{H}\right), 6.99$ (bs, $\left.2 \mathrm{H}\right), 3.91$ (bs, $6 \mathrm{~h}$ ), 3.88 (s, $\left.3 \mathrm{H}\right), 3.76(\mathrm{t}, J=6.3 \mathrm{~Hz}, 2 \mathrm{H})$, 3.50 (t, $J=6.4 \mathrm{~Hz}, 2 \mathrm{H}$ ), 2.28 (pent, $J=6.4 \mathrm{~Hz}, 2 \mathrm{H}$ ); ESIMS $m / z$ (rel intensity) $316 / 318$ $\left(\mathrm{MH}^{+}, 100 / 84\right)$. Anal. $\left(\mathrm{C}_{13} \mathrm{H}_{18} \mathrm{BrNO}_{3}\right) \mathrm{C}, \mathrm{H}, \mathrm{N}$.

\section{2,3,4-Trimethoxybenzylidene-(3-bromo-1-propylamine) (9)}

The hydrobromide salt of 3-bromopropylamine $(3.682 \mathrm{~g}, 16.82 \mathrm{mmol})$ was treated with triethylamine $(3.2 \mathrm{~mL})$ in $\mathrm{CHCl}_{3}(100 \mathrm{~mL})$ and the mixture was allowed to stir at room temperature for $5 \mathrm{~min} .2,3,4$-Trimethoxybenzaldehyde ( $3.000 \mathrm{~g}, 15.29 \mathrm{mmol})$ and magnesium sulfate $(6.000 \mathrm{~g})$ were added and the reaction mixture was stirred at room temperature for 16 h. The reaction mixture was filtered and the filter pad was washed with $\mathrm{CHCl}_{3}(100 \mathrm{~mL})$. The filtrate was washed with water $(3 \times 25 \mathrm{~mL})$ and sat aq $\mathrm{NaCl}(25 \mathrm{~mL})$. The organic layer was dried over sodium sulfate, filtered, and concentrated to provide a yellow viscous oil (4.835 g, 100\%). IR (film) 2938, 1637, 1595, 1496, 1464, 1415, 1297, and $1096 \mathrm{~cm}^{-1} ;{ }^{1} \mathrm{H}$ NMR $\left(\mathrm{CDCl}_{3}\right) \delta 8.58(\mathrm{~s}, 1 \mathrm{H}), 7.71(\mathrm{~d}, J=8.7 \mathrm{~Hz}, 1 \mathrm{H}), 6.73,(\mathrm{~d}, J=8.8 \mathrm{~Hz}, 1 \mathrm{H}), 3.94(\mathrm{~s}, 3 \mathrm{H}), 3.90$ (s, $3 \mathrm{H}), 3.88(\mathrm{~s}, 3 \mathrm{H}), 3.77$ (dt, $J=6.3 \mathrm{~Hz}$ and $1.2 \mathrm{~Hz}, 2 \mathrm{H}), 3.51(\mathrm{t}, J=6.5 \mathrm{~Hz}, 2 \mathrm{H}), 2.30$ (pent, $J=6.4 \mathrm{~Hz}, 2 \mathrm{H}$ ); ESIMS $\mathrm{m} / z$ (rel intensity) $316 / 318\left(\mathrm{MH}^{+}, 100 / 100\right)$. Anal. $\left(\mathrm{C}_{13} \mathrm{H}_{18} \mathrm{BrNO}_{3}\right) \mathrm{C}, \mathrm{H}, \mathrm{N}$.

\section{3,4-Dimethoxybenzylidene-(3-bromo-1-propylamine) (10). ${ }^{16}$}

The hydrobromide salt of 3-bromopropylamine ( $4.348 \mathrm{~g}, 19.86 \mathrm{mmol})$ was treated with triethylamine $(3.8 \mathrm{~mL})$ in $\mathrm{CHCl}_{3}(50 \mathrm{~mL})$ and the mixture was allowed to stir at room temperature for $5 \mathrm{~min}$. 3,4-Dimethoxybenzaldehyde (3.000 g, $18.05 \mathrm{mmol}$ ) and magnesium sulfate $(5.000 \mathrm{~g})$ were added and the reaction mixture was stirred at room temperature for 16 h. The reaction mixture was filtered and the filter pad was washed with $\mathrm{CHCl}_{3}(100 \mathrm{~mL})$. The filtrate was washed with water $(3 \times 25 \mathrm{~mL})$ and sat aq $\mathrm{NaCl}(25 \mathrm{~mL})$. The organic layer was dried over sodium sulfate, filtered, and concentrated to provide a yellow viscous oil $(5.165 \mathrm{~g}$, 100\%). ${ }^{1} \mathrm{H}$ NMR $\left(\mathrm{CDCl}_{3}\right) \delta 8.23(\mathrm{~s}, 1 \mathrm{H}), 7.42(\mathrm{bs}, 1 \mathrm{H}), 7.18(\mathrm{dd}, J=8.2 \mathrm{~Hz}$ and $1.8 \mathrm{~Hz}, 1$ H), 6.90 (d, $J=8.2 \mathrm{~Hz}, 1 \mathrm{H}), 3.97(\mathrm{~s}, 3 \mathrm{H}), 3.92(\mathrm{~s}, 3 \mathrm{H}), 3.75(\mathrm{t}, J=6.3 \mathrm{~Hz}, 2 \mathrm{H}), 3.51$ (t, $J=$ $6.5 \mathrm{~Hz}, 2 \mathrm{H}$ ), 2.30 (pent, $J=6.4 \mathrm{~Hz}, 2 \mathrm{H}$ ). 


\section{2,3-Dimethoxybenzylidene-(3-bromo-1-propylamine) (11)}

The hydrobromide salt of 3-bromopropylamine $(4.348 \mathrm{~g}, 19.86 \mathrm{mmol})$ was treated with triethylamine $(3.8 \mathrm{~mL})$ in $\mathrm{CHCl}_{3}(100 \mathrm{~mL})$ and the mixture was allowed to stir at room temperature for $5 \mathrm{~min}$. 2,3-Dimethoxybenzaldehyde (3.000 g, $18.05 \mathrm{mmol}$ ) and magnesium sulfate $(5.000 \mathrm{~g})$ were added and the reaction mixture was stirred at room temperature for 16 h. The reaction mixture was filtered and the filter pad was washed with $\mathrm{CHCl}_{3}(100 \mathrm{~mL})$. The filtrate was washed with water $(3 \times 50 \mathrm{~mL})$ and sat aq $\mathrm{NaCl}(50 \mathrm{~mL})$. The organic layer was dried over sodium sulfate, filtered, and concentrated to provide a yellow viscous oil (5.128 g, 99\%). IR (film) 2936, 1638, 1582, 1479, 1429, 1269, 1082, $1004 \mathrm{~cm}^{-1} ;{ }^{1} \mathrm{H}$ NMR $\left(\mathrm{CDCl}_{3}\right) \delta$ $8.70(\mathrm{~s}, 1 \mathrm{H}), 7.52(\mathrm{dd}, J=7.8 \mathrm{~Hz}$ and $1.6 \mathrm{~Hz}, 1 \mathrm{H}), 7.09(\mathrm{dt}, J=8.1 \mathrm{~Hz}$ and $0.5 \mathrm{~Hz}, 1 \mathrm{H}), 6.98$ $(\mathrm{dd}, J=8.1 \mathrm{~Hz}$ and $1.6 \mathrm{~Hz}, 1 \mathrm{H}), 3.88(\mathrm{~s}, 3 \mathrm{H}), 3.87(\mathrm{~s}, 3 \mathrm{H}), 3.78(\mathrm{dt}, J=6.3 \mathrm{~Hz}$ and $1.3 \mathrm{~Hz}$, $2 \mathrm{H}$ ), 3.51 (t, $J=6.5 \mathrm{~Hz}, 2 \mathrm{H}$ ), 2.29 (pent, $J=6.4 \mathrm{~Hz}, 2 \mathrm{H}$ ); ESIMS $\mathrm{m} / z$ (rel intensity) 286/288 $\left(\mathrm{MH}^{+}, 100 / 97\right)$. Anal. $\left(\mathrm{C}_{12} \mathrm{H}_{16} \mathrm{BrNO}_{2}\right) \mathrm{C}, \mathrm{H}, \mathrm{N}$.

\section{2,5-Dimethoxybenzylidene-(3-bromo-1-propylamine) (12)}

The hydrobromide salt of 3-bromopropylamine $(4.348 \mathrm{~g}, 19.86 \mathrm{mmol})$ was treated with triethylamine $(3.8 \mathrm{~mL})$ in $\mathrm{CHCl}_{3}(100 \mathrm{~mL})$ and the mixture was allowed to stir at room temperature for $5 \mathrm{~min}$. 2,5-Dimethoxybenzaldehyde (3.000 g, $18.05 \mathrm{mmol})$ and magnesium sulfate $(5.000 \mathrm{~g})$ were added and the reaction mixture was stirred at room temperature for 16 h. The reaction mixture was filtered and the filter pad was washed with $\mathrm{CHCl}_{3}(100 \mathrm{~mL})$. The filtrate was washed with water $(3 \times 50 \mathrm{~mL})$ and sat aq $\mathrm{NaCl}(50 \mathrm{~mL})$. The organic layer was dried over sodium sulfate, filtered, and concentrated to provide a yellow viscous oil ( $4.839 \mathrm{~g}$, 94\%). IR (film) 2939, 1637, 1496, 1277, 1219, and $1044 \mathrm{~cm}^{-1} ;{ }^{1} \mathrm{H} \mathrm{NMR}\left(\mathrm{CDCl}_{3}\right) \delta 8.71(\mathrm{t}$, $J=1.3 \mathrm{~Hz}, 1 \mathrm{H}), 7.46(\mathrm{~d}, J=3.2 \mathrm{~Hz}, 1 \mathrm{H}), 6.95(\mathrm{dd}, J=9.0 \mathrm{~Hz}$ and $3.2 \mathrm{~Hz}, 1 \mathrm{H}), 6.85(\mathrm{~d}, J=$ $9.0 \mathrm{~Hz}, 1 \mathrm{H}), 3.81(\mathrm{~s}, 3 \mathrm{H}), 3.76(\mathrm{~s}, 3 \mathrm{H}), 3.75(\mathrm{dt}, J=6.5 \mathrm{~Hz}$ and $1.4 \mathrm{~Hz}, 2 \mathrm{H}), 3.50(\mathrm{t}, J=6.6$ $\mathrm{Hz}, 2 \mathrm{H}), 2.28$ (pent, $J=6.5 \mathrm{~Hz}, 2 \mathrm{H})$. Anal. $\left(\mathrm{C}_{12} \mathrm{H}_{16} \mathrm{BrNO}_{2}\right) \mathrm{C}, \mathrm{H}, \mathrm{N}$.

\section{4-Methoxybenzylidene-(3-chloro-1-propylamine) (13). 36}

The hydrochloride salt of 3-chloropropylamine $(3.150 \mathrm{~g}, 24.23 \mathrm{mmol})$ was treated with triethylamine $(4.6 \mathrm{~mL})$ in $\mathrm{CHCl}_{3}(100 \mathrm{~mL})$ and the mixture was allowed to stir at room temperature for $5 \mathrm{~min}$. 4-Methoxybenzaldehyde $(3.000 \mathrm{~g}, 22.03 \mathrm{mmol})$ and magnesium sulfate $(6.000 \mathrm{~g})$ were added and the reaction mixture was stirred at room temperature for $16 \mathrm{~h}$. The reaction mixture was filtered and the filter pad was washed with $\mathrm{CHCl}_{3}(50 \mathrm{~mL})$. The filtrate was washed with water $(3 \times 30 \mathrm{~mL})$ and sat aq $\mathrm{NaCl}(30 \mathrm{~mL})$. The organic layer was dried over sodium sulfate, filtered, and concentrated to provide a yellow viscous oil (4.664 g, 100\%). ${ }^{1} \mathrm{H} \mathrm{NMR}\left(\mathrm{CDCl}_{3}\right) \delta 8.25(\mathrm{~s}, 1 \mathrm{H}), 7.68(\mathrm{dd}, J=6.0 \mathrm{~Hz}$ and $2.0 \mathrm{~Hz}, 2 \mathrm{H}), 6.94(\mathrm{dd}, J=$ $6.8 \mathrm{~Hz}$ and $2.0 \mathrm{~Hz}, 2 \mathrm{H}), 3.84(\mathrm{~s}, 3 \mathrm{H}), 3.75(\mathrm{dt}, J=6.4 \mathrm{~Hz}$ and $1.2 \mathrm{~Hz}, 2 \mathrm{H}), 3.65(\mathrm{t}, J=6.4$ $\mathrm{Hz}, 2 \mathrm{H}$ ), 2.20 (pent, $J=6.38 \mathrm{~Hz}, 2 \mathrm{H}$ ).

\section{3-Methoxybenzylidene-(3-chloro-1-propylamine) (14)}

The hydrochloride salt of 3-chloropropylamine $(3.150 \mathrm{~g}, 24.23 \mathrm{mmol})$ was treated with triethylamine $(4.6 \mathrm{~mL})$ in $\mathrm{CHCl}_{3}(100 \mathrm{~mL})$ and the mixture was allowed to stir at room temperature for $5 \mathrm{~min}$. 3-Methoxybenzaldehyde $(3.000 \mathrm{~g}, 22.03 \mathrm{mmol})$ and magnesium sulfate $(6.000 \mathrm{~g})$ were added and the reaction mixture was stirred at room temperature for $16 \mathrm{~h}$. The reaction mixture was filtered and the filter pad was washed with $\mathrm{CHCl}_{3}(50 \mathrm{~mL})$. The filtrate was washed with water $(3 \times 30 \mathrm{~mL})$ and sat aq $\mathrm{NaCl}(30 \mathrm{~mL})$. The organic layer was dried over sodium sulfate, filtered, and concentrated to provide a viscous yellow oil ( $4.538 \mathrm{~g}, 97 \%)$. IR (film) 2838, 1646, 1584, 1265, 1153, and $1040 \mathrm{~cm}^{-1} ;{ }^{1} \mathrm{H} \mathrm{NMR}\left(\mathrm{CDCl}_{3}\right) \delta 8.26(\mathrm{~s}, 1 \mathrm{H})$, 7.31-7.26 (m, $1 \mathrm{H}), 7.21-7.19(\mathrm{~m}, 2 \mathrm{H}), 6.96(\mathrm{ddd}, J=8.0 \mathrm{~Hz}$ and $2.6 \mathrm{~Hz}$ and $1.1 \mathrm{~Hz}, 1 \mathrm{H}$ ), $3.81(\mathrm{~s}, 3 \mathrm{H}), 3.74(\mathrm{dt}, J=6.4 \mathrm{~Hz}$ and $1.2 \mathrm{~Hz}, 2 \mathrm{H}), 3.62(\mathrm{t}, J=6.4 \mathrm{~Hz}, 2 \mathrm{H}), 2.19$ (pent, $J=$ 
$6.4 \mathrm{~Hz}, 2 \mathrm{H})$; ESIMS m/z (rel intensity) 212/214 $\left(\mathrm{MH}^{+}, 100 / 28\right)$. Anal. $\left(\mathrm{C}_{11} \mathrm{H}_{14} \mathrm{ClNO}\right) \mathrm{C}, \mathrm{H}$, N.

\section{2-Methoxybenzylidene-(3-chloro-1-propylamine) (15)}

The hydrochloride salt of 3-chloropropylamine $(3.457 \mathrm{~g}, 26.44 \mathrm{mmol})$ was treated with triethylamine $(4.6 \mathrm{~mL})$ in $\mathrm{CHCl}_{3}(100 \mathrm{~mL})$ and the mixture was allowed to stir at room temperature for $5 \mathrm{~min}$. 2-Methoxybenzaldehyde $(3.000 \mathrm{~g}, 22.03 \mathrm{mmol})$ and magnesium sulfate $(6.000 \mathrm{~g})$ were added and the reaction mixture was stirred at room temperature for $16 \mathrm{~h}$. The reaction mixture was filtered and the filter pad was washed with $\mathrm{CHCl}_{3}(100 \mathrm{~mL})$. The filtrate was washed with water $(3 \times 50 \mathrm{~mL})$ and sat aq $\mathrm{NaCl}(50 \mathrm{~mL})$. The organic layer was dried over sodium sulfate, filtered, and concentrated to provide a viscous yellow oil (4.639 $\mathrm{g}, 99 \%)$. IR (film) 1638, 1600, 1488, 1465, 1287, 1248, 1087, and $756 \mathrm{~cm}^{-1} ;{ }^{1} \mathrm{H} \mathrm{NMR}\left(\mathrm{CDCl}_{3}\right) \delta 8.75$ $(\mathrm{s}, 1 \mathrm{H}), 7.94(\mathrm{dd}, J=7.7 \mathrm{~Hz}$ and $1.8 \mathrm{~Hz}, 1 \mathrm{H}), 7.41(\mathrm{~m}, 1 \mathrm{H}), 7.00(\mathrm{t}, J=7.5 \mathrm{~Hz}, 1 \mathrm{H}), 6.93$ $(\mathrm{d}, J=8.3 \mathrm{~Hz}, 1 \mathrm{H}), 3.87(\mathrm{~s}, 3 \mathrm{H}), 3.78(\mathrm{dt}, J=6.4 \mathrm{~Hz}$ and $1.3 \mathrm{~Hz}, 2 \mathrm{H}), 3.66(\mathrm{t}, J=6.5 \mathrm{~Hz}, 2$ $\mathrm{H}), 2.22$ (pent., $J=6.4 \mathrm{~Hz}, 2 \mathrm{H}$ ). Anal. $\left(\mathrm{C}_{11} \mathrm{H}_{14} \mathrm{ClNO}\right) \mathrm{C}, \mathrm{H}, \mathrm{N}$.

\section{cis- $\mathrm{N}$-(3-Bromopropyl)-4-carboxy-3,4-dihydro-3-(3,4,5-trimethoxyphenyl)-7-nitro-1(2H) isoquinolone (16)}

4-Nitrohomophthalic anhydride ${ }^{28}$ (7) (3.222 g, $15.56 \mathrm{mmol}$ ) was added to a chloroform (200 $\mathrm{mL}$ ) solution of 3,4,5-trimethoxybenzylidene-(3-bromo-1-propylamine) (8) (4.919 g, 15.56 $\mathrm{mmol}$ ) and the reaction mixture was allowed to stir at room temperature for $16 \mathrm{~h}$. The precipitate was filtered, washed with chloroform $(50 \mathrm{~mL})$, and dried to provide an off-white solid $(\sim 0.5$ $\mathrm{g})$. The filtrate was concentrated to a volume of $50 \mathrm{~mL}$, and diethyl ether $(20 \mathrm{~mL})$ was added. The precipitate was filtered, washed with diethyl ether $(50 \mathrm{~mL})$, and the isolated precipitates were combined and dried to provide an off-white solid $(3.009 \mathrm{~g}, 37 \%): \mathrm{mp} 142-145^{\circ} \mathrm{C}$. IR (KBr) 3082, 1749, 1629, 1592, 1526, 1465, 1351, 1239, 1171, and $1128 \mathrm{~cm}^{-1}$; ${ }^{1} \mathrm{H}$ NMR $\left(\mathrm{DMSO}-d_{6}\right) \delta 8.72(\mathrm{~d}, J=2.6 \mathrm{~Hz}, 1 \mathrm{H}), 8.41(\mathrm{dd}, J=8.6 \mathrm{~Hz}$ and $2.6 \mathrm{~Hz}, 1 \mathrm{H}), 7.96(\mathrm{~d}, J=8.7$ $\mathrm{Hz}, 1 \mathrm{H}), 6.26(\mathrm{~s}, 2 \mathrm{H}), 5.21(\mathrm{~d}, J=6.1 \mathrm{~Hz}, 1 \mathrm{H}), 5.03$ (d, J=6.1 Hz, $1 \mathrm{H}), 3.98$ (m, $1 \mathrm{H})$, 3.63-3.55 (m, $11 \mathrm{H}), 3.13$ (m, $1 \mathrm{H}), 2.21-2.07$ (m, $2 \mathrm{H}$ ); MALDIMS $m / z$ (rel intensity) 523/525 $\left(\mathrm{MH}^{+}, 65 / 50\right), 478 / 480\left(\mathrm{MH}^{+}-\mathrm{COOH}, 80 / 100\right)$. Anal. $\left(\mathrm{C}_{22} \mathrm{H}_{23} \mathrm{BrN}_{2} \mathrm{O}_{8}\right) \mathrm{C}, \mathrm{H}, \mathrm{N}$.

\section{cis- $N$-(3-Bromopropyl)-4-carboxy-3,4-dihydro-3-(2,3,4-trimethoxyphenyl)-7-nitro-1(2H) isoquinolone (17)}

4-Nitrohomophthalic anhydride ${ }^{28}$ (7) (2.948 g, $14.23 \mathrm{mmol}$ ) was added to a chloroform (125 $\mathrm{mL}$ ) solution of 2,3,4-trimethoxybenzylidene-(3-bromo-1-propylamine) (9) (4.500 g, 14.23 $\mathrm{mmol})$ and the reaction mixture was allowed to stir at room temperature for $4.5 \mathrm{~h}$. The precipitate was filtered, washed with chloroform $(50 \mathrm{~mL})$, diethyl ether $(50 \mathrm{~mL})$, and dried to provide an off-white solid (6.271 g, 84\%): $\mathrm{mp} 133-136^{\circ} \mathrm{C}$. IR (KBr) 2947, 1737, 1632, 1526, 1496, 1465, 1418, 1348, 1294, 1179, and $1100 \mathrm{~cm}^{-1} ;{ }^{1} \mathrm{H} \mathrm{NMR}\left(\mathrm{CD}_{3} \mathrm{OD}\right) \delta 8.87(\mathrm{~d}, J=2.5$ $\mathrm{Hz}, 1 \mathrm{H}), 8.39(\mathrm{dd}, J=8.6 \mathrm{~Hz}$ and $2.5 \mathrm{~Hz}, 1 \mathrm{H}), 7.79-7.76(\mathrm{~m}, 1 \mathrm{H}), 6.53(\mathrm{~d}, J=8.8 \mathrm{~Hz}, 1 \mathrm{H})$, $6.47(\mathrm{~d}, J=8.8 \mathrm{~Hz}, 1 \mathrm{H}), 5.63(\mathrm{~d}, J=6.8 \mathrm{~Hz}, 1 \mathrm{H}), 4.90(\mathrm{~d}, J=7.0 \mathrm{~Hz}, 1 \mathrm{H}), 3.93(\mathrm{~m}, 1 \mathrm{H})$, 3.83 (s, $3 \mathrm{H}), 3.75$ (s, $3 \mathrm{H}), 3.74(\mathrm{~s}, 3 \mathrm{H}), 3.49$ (m, $2 \mathrm{H}), 3.29(\mathrm{~m}, 1 \mathrm{H}), 2.25(\mathrm{~m}, 1 \mathrm{H}), 2.09$ (m, $2 \mathrm{H})$; ESIMS $m / z$ (rel intensity) 545/547 $\left(\mathrm{MH}^{+}+\mathrm{Na}, 100 / 97\right), 523 / 525\left(\mathrm{MH}^{+}, 21 / 22\right)$. Anal. $\left(\mathrm{C}_{22} \mathrm{H}_{23} \mathrm{BrN}_{2} \mathrm{O}_{8}\right) \mathrm{C}, \mathrm{H}, \mathrm{N}$.

\section{cis- $\mathrm{N}$-(3-Bromopropyl)-4-carboxy-3,4-dihydro-3-(3,4-dimethoxyphenyl)-7-nitro-1(2H) isoquinolone (18)}

4-Nitrohomophthalic anhydride ${ }^{28}$ (7) $(5.165 \mathrm{~g}, 18.05 \mathrm{mmol})$ was added to a chloroform (150 $\mathrm{mL}$ ) solution of 3,4-dimethoxybenzylidene-(3-bromo-1-propylamine) (10) (3.739 g, 18.05 $\mathrm{mmol}$ ) and the reaction mixture was allowed to stir at room temperature for $3 \mathrm{~h}$. The precipitate was filtered, washed with chloroform $(100 \mathrm{~mL})$, and dried to provide an off-white solid (5.910 
g, 66\%): $\mathrm{mp} 161-163^{\circ} \mathrm{C}$. IR (KBr) 3046, 1751, 1633, 1520, 1352, 1259, 1178, 1146, and 1030 $\mathrm{cm}^{-1} ;{ }_{1}^{1} \mathrm{H}$ NMR $\left(\mathrm{CD}_{-3} \mathrm{OD}\right) \delta 8.89(\mathrm{~d}, J=2.5 \mathrm{~Hz}, 1 \mathrm{H}), 8.38(\mathrm{dd}, J=8.6 \mathrm{~Hz}$ and $2.6 \mathrm{~Hz}, 1 \mathrm{H})$, 8.00-7.97 (m, $1 \mathrm{H}), 6.78(\mathrm{~d}, J=8.4 \mathrm{~Hz}, 1 \mathrm{H}), 6.65(\mathrm{~d}, J=2.2 \mathrm{~Hz}, 1 \mathrm{H}), 6.58(\mathrm{dd}, J=8.3 \mathrm{~Hz}$ and $2.2 \mathrm{~Hz}, 1 \mathrm{H}), 5.27(\mathrm{~d}, J=6.1 \mathrm{~Hz}, 1 \mathrm{H}), 4.89(\mathrm{~d}, J=6.1 \mathrm{~Hz}, 1 \mathrm{H}), 3.99(\mathrm{~m}, 1 \mathrm{H}), 3.74(\mathrm{~s}, 3$ H), $3.64(\mathrm{~s}, 3 \mathrm{H}), 3.48(\mathrm{~m}, 2 \mathrm{H}), 3.28(\mathrm{~m}, 1 \mathrm{H}), 2.27(\mathrm{~m}, 1 \mathrm{H}), 2.14(\mathrm{~m}, 1 \mathrm{H})$; ESIMS $\mathrm{m} / z(\mathrm{rel}$ intensity) $493 / 495\left(\mathrm{MH}^{+}, 100 / 96\right)$. Anal. $\left(\mathrm{C}_{21} \mathrm{H}_{21} \mathrm{BrN}_{2} \mathrm{O}_{7}\right) \mathrm{C}, \mathrm{H}, \mathrm{N}$.

\section{cis- $N$-(3-Bromopropyl)-4-carboxy-3,4-dihydro-3-(2,3-dimethoxyphenyl)-7-nitro-1(2H) isoquinolone (19)}

4-Nitrohomophthalic anhydride 28 (7) $(3.258 \mathrm{~g}, 15.73 \mathrm{mmol})$ was added to a chloroform (125 $\mathrm{mL}$ ) solution of 2,3-dimethoxybenzylidene-(3-bromo-1-propylamine) (11) (4.500 g, 15.73 $\mathrm{mmol}$ ) and the reaction mixture was allowed to stir at room temperature for $16 \mathrm{~h}$. The precipitate was filtered, washed with chloroform $(50 \mathrm{~mL})$, diethyl ether $(50 \mathrm{~mL})$, and dried to provide an off-white solid (6.737 g, 87\%): $\mathrm{mp} 161-163^{\circ} \mathrm{C}$. IR (KBr) 2947, 1745, 1630, 1524, 1481, 1345 , 1274, and $1179 \mathrm{~cm}^{-1} ;{ }^{1} \mathrm{H}$ NMR $\left(\mathrm{CD}_{3} \mathrm{OD}\right) \delta 8.87(\mathrm{~d}, J=2.5 \mathrm{~Hz}, 1 \mathrm{H}), 8.40(\mathrm{dd}, J=8.6 \mathrm{~Hz}$ and $2.5 \mathrm{~Hz}, 1 \mathrm{H}), 7.80(\mathrm{dd}, J=8.7 \mathrm{~Hz}$ and $2.9 \mathrm{~Hz}, 1 \mathrm{H}), 6.93(\mathrm{dd}, J=8.2 \mathrm{~Hz}$ and $1.3 \mathrm{~Hz}, 1 \mathrm{H}), 6.82$ (t, $J=8.1 \mathrm{~Hz}, 1 \mathrm{H}), 6.35(\mathrm{dd}, J=7.9 \mathrm{~Hz}$ and $1.4 \mathrm{~Hz}, 1 \mathrm{H}), 5.75(\mathrm{~d}, J=6.8 \mathrm{~Hz}, 1 \mathrm{H}), 4.94(\mathrm{~d}$, $J=6.5 \mathrm{~Hz}, 1 \mathrm{H}), 3.98(\mathrm{~m}, 1 \mathrm{H}), 3.81(\mathrm{~s}, 6 \mathrm{H}), 3.51(\mathrm{~m}, 2 \mathrm{H}), 3.26(\mathrm{~m}, 1 \mathrm{H}), 2.26(\mathrm{~m}, 1 \mathrm{H}), 2.11$ $(\mathrm{m}, 1 \mathrm{H})$; ESIMS $m / z$ (rel intensity) 493/495 $\left(\mathrm{MH}^{+}, 100 / 100\right)$. Anal. $\left(\mathrm{C}_{21} \mathrm{H}_{21} \mathrm{BrN}_{2} \mathrm{O}_{7}\right) \mathrm{C}, \mathrm{H}$, N.

\section{cis- $N$-(3-Bromopropyl)-4-carboxy-3,4-dihydro-3-(2,5-dimethoxyphenyl)-7-nitro-1(2H) isoquinolone (20)}

4-Nitrohomophthalic anhydride 28 (7) $(3.258 \mathrm{~g}, 15.73 \mathrm{mmol})$ was added to a chloroform (125 $\mathrm{mL}$ ) solution of 2,5-dimethoxybenzylidene-(3-bromo-1-propylamine) (12) (4.500 g, 15.73 $\mathrm{mmol}$ ) and the reaction mixture was allowed to stir at room temperature for $4 \mathrm{~h}$. The precipitate was filtered, washed with chloroform $(100 \mathrm{~mL})$, and dried to provide an off-white solid (4.048 g, 52\%): $\mathrm{mp} 147-150^{\circ} \mathrm{C}$. IR (KBr) 2953, 1745, 1627, 1512, 1344, 1271, 1225, 1181, and 1051 $\mathrm{cm}^{-1} ;{ }^{1} \mathrm{H}$ NMR $\left(\mathrm{CD}_{3} \mathrm{OD}\right) \delta 8.88(\mathrm{~d}, J=2.5 \mathrm{~Hz}, 1 \mathrm{H}), 8.38(\mathrm{dd}, J=8.6 \mathrm{~Hz}$ and $2.5 \mathrm{~Hz}, 1 \mathrm{H})$, $7.74(\mathrm{dd}, J=8.5 \mathrm{~Hz}$ and $1.5 \mathrm{~Hz}, 1 \mathrm{H}), 6.89(\mathrm{~d}, J=9.0 \mathrm{~Hz}, 1 \mathrm{H}), 6.81(\mathrm{dd}, J=9.0 \mathrm{~Hz}$ and 2.9 $\mathrm{Hz}, 1 \mathrm{H}), 6.31(\mathrm{~d}, J=2.9 \mathrm{~Hz}, 1 \mathrm{H}), 5.73(\mathrm{~d}, J=6.5 \mathrm{~Hz}, 1 \mathrm{H}), 4.84(\mathrm{~d}, J=6.5 \mathrm{~Hz}, 1 \mathrm{H}), 3.99$ $(\mathrm{m}, 1 \mathrm{H}), 3.68(\mathrm{~s}, 3 \mathrm{H}), 3.52(\mathrm{~s}, 3 \mathrm{H}), 3.44(\mathrm{~m}, 2 \mathrm{H}), 3.28(\mathrm{~m}, 1 \mathrm{H}), 2.23(\mathrm{~m}, 1 \mathrm{H}), 2.11(\mathrm{~m}, 1$ $\mathrm{H}$ ); ESIMS $m / z$ (rel intensity) 493/495 $\left(\mathrm{MH}^{+}, 100 / 94\right)$. Anal. $\left(\mathrm{C}_{21} \mathrm{H}_{21} \mathrm{BrN}_{2} \mathrm{O}_{7}\right) \mathrm{C}, \mathrm{H}, \mathrm{N}$.

\section{cis-4-Carboxy- $\mathrm{N}$-(3-chloropropyl)-3,4-dihydro-3-(4-methoxyphenyl)-7-nitro-1(2H) isoquinolone (21)}

4-Nitrohomophthalic anhydride 28 (7) (4.563 g, $22.03 \mathrm{mmol})$ was added to a chloroform (125 $\mathrm{mL}$ ) solution of 4-methoxybenzylidene-(3-chloro-1-propylamine) (13) (4.664 g, $22.03 \mathrm{mmol})$ and the reaction mixture was allowed to stir at room temperature for $16 \mathrm{~h}$. The precipitate was filtered, washed with chloroform $(50 \mathrm{~mL})$, and dried to provide an off-white solid $(7.018 \mathrm{~g}$, 76\%): $\mathrm{mp} 163-164{ }^{\circ} \mathrm{C}$. IR (KBr) 2957, 1739, 1633, 1528, 1347, 1296, 1256, and 1177 $\mathrm{cm}^{-1} ;{ }^{1} \mathrm{H} \mathrm{NMR}\left(\mathrm{CD}_{3} \mathrm{OD}\right) \delta 8.89(\mathrm{~d}, J=2.5 \mathrm{~Hz}, 1 \mathrm{H}), 8.38(\mathrm{dd}, J=8.7 \mathrm{~Hz}$ and $2.6 \mathrm{~Hz}, 1 \mathrm{H})$, $7.98(\mathrm{dd}, J=8.7 \mathrm{~Hz}$ and $1.0 \mathrm{~Hz}, 1 \mathrm{H}), 6.97(\mathrm{dd}, J=6.7 \mathrm{~Hz}$ and $2.1 \mathrm{~Hz}, 2 \mathrm{H}), 6.76(\mathrm{dd}, J=6.8$ $\mathrm{Hz}$ and $2.1 \mathrm{~Hz}, 2 \mathrm{H}), 5.25(\mathrm{~d}, J=6.3 \mathrm{~Hz}, 1 \mathrm{H}), 4.90(\mathrm{~d}, J=6.4 \mathrm{~Hz}, 1 \mathrm{H}), 4.01(\mathrm{~m}, 1 \mathrm{H}), 3.70$ $(\mathrm{s}, 3 \mathrm{H}), 3.62(\mathrm{~m}, 2 \mathrm{H}), 3.26(\mathrm{~m}, 1 \mathrm{H}), 2.17(\mathrm{~m}, 1 \mathrm{H}), 2.04(\mathrm{~m}, 1 \mathrm{H})$; ESIMS $\mathrm{m} / z$ (rel intensity) 419/421 $\left(\mathrm{MH}^{+}, 100 / 35\right)$. Anal. $\left(\mathrm{C}_{20} \mathrm{H}_{19} \mathrm{ClN}_{2} \mathrm{O}_{6} \cdot 0.75 \mathrm{H}_{2} \mathrm{O}\right) \mathrm{C}, \mathrm{H}, \mathrm{N}$.

\section{cis-4-Carboxy- $N$-(3-chloropropyl)-3,4-dihydro-3-(3-methoxyphenyl)-7-nitro-1(2H) isoquinolone (22)}

4-Nitrohomophthalic anhydride 28 (7) $(3.914 \mathrm{~g}, 18.90 \mathrm{mmol})$ was added to a chloroform (125 $\mathrm{mL}$ ) solution of 3-methoxybenzylidene-(3-chloro-1-propylamine) (14) (4.000 g, $18.90 \mathrm{mmol}$ ) 
and the reaction mixture was allowed to stir at room temperature for $16 \mathrm{~h}$. The precipitate was filtered, washed with chloroform $(100 \mathrm{~mL})$, and dried to provide a white solid $(4.477 \mathrm{~g}, 57 \%)$ : $\mathrm{mp} 154-157^{\circ} \mathrm{C}$. IR (KBr) $1743,1633,1527,1489,1348$, and $1179 \mathrm{~cm}^{-1} ;{ }^{1} \mathrm{H}$ NMR $\left(\mathrm{CD}_{3} \mathrm{OD}\right)$ $\delta 8.89(\mathrm{~d}, J=2.5 \mathrm{~Hz}, 1 \mathrm{H}), 8.38(\mathrm{dd}, \mathrm{J}=8.6 \mathrm{~Hz}$ and $2.6 \mathrm{~Hz}, 1 \mathrm{H}), 7.99(\mathrm{dd}, J=8.6 \mathrm{~Hz}$ and 1.0 $\mathrm{Hz}, 1 \mathrm{H}), 7.14(\mathrm{~m}, 1 \mathrm{H}), 6.84(\mathrm{ddd}, J=8.3 \mathrm{~Hz}$ and $2.4 \mathrm{~Hz}$ and $1.00 \mathrm{~Hz}, 1 \mathrm{H}), 6.61(\mathrm{~m}, 2 \mathrm{H})$, $5.28(\mathrm{~d}, J=6.4 \mathrm{~Hz}, 1 \mathrm{H}), 4.95(\mathrm{~d}, J=6.4 \mathrm{~Hz}, 1 \mathrm{H}), 4.05(\mathrm{~m}, 1 \mathrm{H}), 3.65(\mathrm{~s}, 3 \mathrm{H}), 3.61(\mathrm{~m}, 2 \mathrm{H})$, 3.29 (m, $1 \mathrm{H}), 2.20-2.00(\mathrm{~m}, 2 \mathrm{H})$; negative ion ESIMS $\mathrm{m} / z$ (rel intensity) 417/419 [(M-H) ${ }^{-}$, 100/34]. Anal. $\left(\mathrm{C}_{20} \mathrm{H}_{19} \mathrm{ClN}_{2} \mathrm{O}_{6}\right) \mathrm{C}, \mathrm{H}, \mathrm{N}$.

\section{cis-4-Carboxy- $N$-(3-chloropropyl)-3,4-dihydro-3-(2-methoxyphenyl)-7-nitro-1(2H) isoquinolone (23)}

4-Nitrohomophthalic anhydride 28 (7) $(3.914 \mathrm{~g}, 18.90 \mathrm{mmol})$ was added to a chloroform (125 $\mathrm{mL}$ ) solution of 2-methoxybenzylidene-(3-chloro-1-propylamine) (15) (4.000 g, $18.90 \mathrm{mmol}$ ) and the reaction mixture was allowed to stir at room temperature for $16 \mathrm{~h}$. The precipitate was filtered, washed with chloroform $(100 \mathrm{~mL})$, diethyl ether $(50 \mathrm{~mL})$, and dried to provide an offwhite solid (5.455 g, 69\%): $\mathrm{mp} 159-162{ }^{\circ} \mathrm{C}$. IR (KBr) 3076, 1753, 1626, 1525, 1489, 1352, $1289,1248,1162$, and $759 \mathrm{~cm}^{-1} ;{ }^{1} \mathrm{H}$ NMR $\left(\mathrm{CD}_{3} \mathrm{OD}\right) \delta 8.89(\mathrm{~d}, J=2.5 \mathrm{~Hz}, 1 \mathrm{H}), 8.37(\mathrm{dd}, J$ $=8.6 \mathrm{~Hz}$ and $2.5 \mathrm{~Hz}, 1 \mathrm{H}), 7.71(\mathrm{~m}, 1 \mathrm{H}), 7.26(\mathrm{~m}, 1 \mathrm{H}), 6.96(\mathrm{~d}, J=8.1 \mathrm{~Hz}, 1 \mathrm{H}), 6.77(\mathrm{~m}, 2$ H), $5.78(\mathrm{~d}, J=6.5 \mathrm{~Hz}, 1 \mathrm{H}), 4.86(\mathrm{~d}, J=6.4 \mathrm{~Hz}, 1 \mathrm{H}), 4.01(\mathrm{~m}, 1 \mathrm{H}), 3.74(\mathrm{~s}, 3 \mathrm{H}), 3.63(\mathrm{~m}$, $2 \mathrm{H}), 3.22(\mathrm{~m}, 1 \mathrm{H}), 2.16(\mathrm{~m}, 1 \mathrm{H}), 2.04(\mathrm{~m}, 1 \mathrm{H})$; ESIMS $\mathrm{m} / z$ (rel intensity) 419/421 ( $\mathrm{MH}^{+}$, 100/34). Anal. $\left(\mathrm{C}_{20} \mathrm{H}_{19} \mathrm{ClN}_{2} \mathrm{O}_{6} \cdot 0.25 \mathrm{H}_{2} \mathrm{O}\right) \mathrm{C}, \mathrm{H}, \mathrm{N}$.

\section{6-(3-Bromopropyl)-5,6-dihydro-7,8,9-trimethoxy-3-nitro-5,11-dioxo-11H-indeno[1,2-c] isoquinoline (24)}

Thionyl chloride (1.5 mL) was added to a solution of cis- $\mathrm{N}$-(3-bromopropyl)-4-carboxy-3,4dihydro-3-(2,3,4-trimethoxyphenyl)-7-nitro-1(2H)isoquinolone (17) $(0.500 \mathrm{~g}, 0.955 \mathrm{mmol})$ in benzene $(50 \mathrm{~mL})$. The reaction mixture was heated at reflux for $30 \mathrm{~min}$, allowed to cool to room temperature, and concentrated. The residue was diluted with nitrobenzene $(10 \mathrm{~mL})$, chilled in an ice bath, and aluminum chloride was added $(0.255 \mathrm{~g}, 1.910 \mathrm{mmol})$. The reaction mixture was removed from the bath and heated at $100{ }^{\circ} \mathrm{C}$ for $1 \mathrm{~h}$. Water $(100 \mathrm{~mL})$ was added and the solution was extracted with $\mathrm{CHCl}_{3}(3 \times 50 \mathrm{~mL})$. The combined organic layer was washed with sat aq $\mathrm{NaHCO}_{3}(3 \times 50 \mathrm{~mL})$, sat aq $\mathrm{NaCl}(50 \mathrm{~mL})$, and dried over sodium sulfate. The solution was concentrated, hexanes $(250 \mathrm{~mL})$ were added, and the liquid was decanted. The solid was washed with hexanes $(100 \mathrm{~mL})$ and the liquid was again decanted. The solid was purified by flash column chromatography $\left(\mathrm{SiO}_{2}\right)$, eluting with chloroform, to provide a red solid $(0.306 \mathrm{~g}, 64 \%)$ : $\mathrm{mp} 179-181^{\circ} \mathrm{C}$. IR (KBr) 1701, 1662, 1612, 1548, 1494, 1463, 1415, 1365,1331 , and $1144 \mathrm{~cm}^{-1} ;{ }^{1} \mathrm{H}$ NMR (DMSO- $\left.d_{6}\right) \delta 8.83(\mathrm{~d}, J=2.4 \mathrm{~Hz}, 1 \mathrm{H}), 8.71(\mathrm{~d}, J=9.1$ $\mathrm{Hz}, 1 \mathrm{H}), 8.53(\mathrm{dd}, J=9.0 \mathrm{~Hz}$ and $2.5 \mathrm{~Hz}, 1 \mathrm{H}), 7.19(\mathrm{~s}, 1 \mathrm{H}), 4.73(\mathrm{t}, J=6.6 \mathrm{~Hz}, 2 \mathrm{H}), 3.97$ (s, $3 \mathrm{H}$ ), 3.65 (s, $3 \mathrm{H}$ ), 3.84 (s, $3 \mathrm{H}$ ), 3.59 (t, $J=6.7 \mathrm{~Hz}, 2 \mathrm{H}$ ), 2.33 (pent., $J=6.9 \mathrm{~Hz}, 2 \mathrm{H}$ ); MALDIMS $m / z$ (rel intensity) 503/505 ( $\left.\mathrm{MH}^{+}, 74 / 79\right), 423\left(\mathrm{MH}^{+}-\mathrm{HBr}, 100\right)$. Anal. $\left(\mathrm{C}_{22} \mathrm{H}_{19} \mathrm{BrN}_{2} \mathrm{O}_{7}\right) \mathrm{C}, \mathrm{H}, \mathrm{N}$.

\section{6-(3-Bromopropyl)-5,6-dihydro-8,9-dimethoxy-3-nitro-5,11-dioxo-11H-indeno[1,2-c] isoquinoline (25)}

Thionyl chloride ( $2 \mathrm{~mL}$ ) was added to a solution of $\mathrm{cis}$ - $\mathrm{N}$-(3-bromopropyl)-4-carboxy-3,4dihydro-3-(3,4-dimethoxyphenyl)-7-nitro-1(2H)isoquinolone (18) $(1.000 \mathrm{~g}, 2.027 \mathrm{mmol})$ in benzene $(50 \mathrm{~mL})$. The reaction mixture was heated at reflux for $30 \mathrm{~min}$, allowed to cool to room temperature, and concentrated. The residue was diluted with nitrobenzene $(20 \mathrm{~mL})$, chilled in an ice bath, and aluminum chloride $(0.541 \mathrm{~g}, 4.054 \mathrm{mmol})$ was added. The reaction mixture was removed from the bath and heated at $100^{\circ} \mathrm{C}$ for $1 \mathrm{~h}$. Water $(100 \mathrm{~mL})$ was added and the solution was extracted with $\mathrm{CHCl}_{3}(4 \times 30 \mathrm{~mL})$. The combined organic layer was 
washed with sat aq $\mathrm{NaHCO}_{3}(3 \times 30 \mathrm{~mL})$, sat aq $\mathrm{NaCl}(30 \mathrm{~mL})$, and dried over sodium sulfate. The solution was concentrated, hexanes $(250 \mathrm{~mL})$ were added, and the liquid was decanted. The solid was washed with hexanes $(100 \mathrm{~mL})$ and the liquid was again decanted. The solid was purified by flash column chromatography $\left(\mathrm{SiO}_{2}\right)$, eluting with chloroform, to provide a brown-green solid $(0.813 \mathrm{~g}, 84 \%)$ : $\mathrm{mp} 247-250{ }^{\circ} \mathrm{C}$. IR (KBr) 1675, 1615, 1559, 1510, 1335 , 1303 , and $754 \mathrm{~cm}^{-1} ;{ }^{1} \mathrm{H}$ NMR (DMSO- $\left.d_{6}\right) \delta 8.83(\mathrm{~d}, J=2.4 \mathrm{~Hz}, 1 \mathrm{H}), 8.61(\mathrm{~d}, J=8.8 \mathrm{~Hz}, 1$ H), $8.51(\mathrm{dd}, J=8.8 \mathrm{~Hz}$ and $2.5 \mathrm{~Hz}, 1 \mathrm{H}), 7.24(\mathrm{bs}, 2 \mathrm{H}), 4.66(\mathrm{t}, J=7.1 \mathrm{~Hz}, 2 \mathrm{H}), 3.97(\mathrm{~s}, 3$ H), $3.91(\mathrm{~s}, 3 \mathrm{H}), 3.80(\mathrm{t}, J=6.3 \mathrm{~Hz}, 2 \mathrm{H}), 2.44(\mathrm{~m}, 2 \mathrm{H})$; ESIMS $\mathrm{m} / z$ (rel intensity) 473/475 $\left(\mathrm{MH}^{+}, 100 / 85\right)$. Anal. $\left(\mathrm{C}_{21} \mathrm{H}_{17} \mathrm{BrN}_{2} \mathrm{O}_{6}\right) \mathrm{C}, \mathrm{H}, \mathrm{N}$.

\section{6-(3-Bromopropyl)-5,6-dihydro-7,8-dimethoxy-3-nitro-5,11-dioxo-11 $H$-indeno[1,2-c] isoquinoline (26)}

Thionyl chloride $(1.5 \mathrm{~mL})$ was added to a solution of $c i s-\mathrm{N}$-(3-bromopropyl)-4-carboxy-3,4dihydro-3-(2,3-dimethoxyphenyl)-7-nitro-1(2H)isoquinolone (19) $(0.500 \mathrm{~g}, 1.014 \mathrm{mmol})$ in benzene $(50 \mathrm{~mL})$. The reaction mixture was heated at reflux for $30 \mathrm{~min}$, allowed to cool to room temperature, and concentrated. The residue was diluted with nitrobenzene $(10 \mathrm{~mL})$, chilled in an ice bath, and aluminum chloride was added $(0.255 \mathrm{~g}, 1.910 \mathrm{mmol})$. The reaction mixture was removed from the bath and heated at $100{ }^{\circ} \mathrm{C}$ for $1 \mathrm{~h}$. Water $(100 \mathrm{~mL})$ was added and the solution was extracted with $\mathrm{CHCl}_{3}(5 \times 60 \mathrm{~mL})$. The combined organic layer was washed with sat aq $\mathrm{NaHCO}_{3}(3 \times 50 \mathrm{~mL})$, sat aq $\mathrm{NaCl}(50 \mathrm{~mL})$, and dried over sodium sulfate. The solution was concentrated, hexanes $(250 \mathrm{~mL})$ were added, and the liquid was decanted. The solid was washed with hexanes $(100 \mathrm{~mL})$ and the liquid was again decanted. The solid was purified by flash column chromatography $\left(\mathrm{SiO}_{2}\right)$, eluting with chloroform, to provide a yellow solid (0.160 g, 33\%): $\mathrm{mp} 245^{\circ} \mathrm{C}$ (dec.). IR (KBr) 1699, 1661, 1613, 1552, 1499, 1479, $1429,1338,1277,1208$, and $1051 \mathrm{~cm}^{-1} ;{ }^{1} \mathrm{H}$ NMR (DMSO- $\left.d_{6}\right) \delta 8.89(\mathrm{~d}, J=2.3 \mathrm{~Hz}, 1 \mathrm{H})$, $8.84(\mathrm{~d}, J=8.9 \mathrm{~Hz}, 1 \mathrm{H}), 8.58(\mathrm{dd}, J=9.0 \mathrm{~Hz}$ and $2.5 \mathrm{~Hz}, 1 \mathrm{H}), 7.45(\mathrm{~d}, J=7.9 \mathrm{~Hz}, 1 \mathrm{H}), 7.19$ $(\mathrm{d}, J=8.1 \mathrm{~Hz}, 1 \mathrm{H}), 4.76(\mathrm{t}, J=6.9 \mathrm{~Hz}, 2 \mathrm{H}), 3.94(\mathrm{~s}, 3 \mathrm{H}), 3.91$ (s, $3 \mathrm{H}), 3.58$ (t, $J=6.7 \mathrm{~Hz}$, $2 \mathrm{H}), 2.33(\mathrm{~m}, 2 \mathrm{H})$; MALDIMS $\mathrm{m} / z$ (rel intensity) 473/475 $\left(\mathrm{MH}^{+}, 65 / 62\right), 393\left(\mathrm{MH}^{+}-\mathrm{HBr}\right.$, 100). Anal. $\left(\mathrm{C}_{21} \mathrm{H}_{17} \mathrm{BrN}_{2} \mathrm{O}_{6}\right) \mathrm{C}, \mathrm{H}, \mathrm{N}$.

\section{6-(3-Chloropropyl)-5,6-dihydro-9-methoxy-3-nitro-5,11-dioxo-11H-indeno[1,2-c]isoquinoline} (27)

Thionyl chloride ( $3 \mathrm{~mL}$ ) was added to a solution of cis-4-carboxy- $N$-(3-chloropropyl)-3,4dihydro-3-(4-methoxyphenyl)-7-nitro-1(2H)isoquinolone (21) $(1.000 \mathrm{~g}, 2.388 \mathrm{mmol})$ in benzene $(50 \mathrm{~mL})$. The reaction mixture was heated at reflux for $30 \mathrm{~min}$, allowed to cool to room temperature, and concentrated. The residue was diluted with nitrobenzene $(20 \mathrm{~mL})$, chilled in an ice bath, and aluminum chloride $(0.637 \mathrm{~g}, 4.775 \mathrm{mmol})$ was added. The reaction mixture was removed from the bath and heated at $100{ }^{\circ} \mathrm{C}$ for $1 \mathrm{~h}$. Water $(100 \mathrm{~mL})$ was added and the solution was extracted with $\mathrm{CHCl}_{3}(3 \times 50 \mathrm{~mL})$. The combined organic layer was washed with sat aq $\mathrm{NaHCO}_{3}(3 \times 50 \mathrm{~mL})$, sat aq $\mathrm{NaCl}(50 \mathrm{~mL})$, and dried over sodium sulfate. The solution was concentrated, hexanes $(250 \mathrm{~mL})$ were added, and the liquid was decanted. The solid was washed with hexanes $(100 \mathrm{~mL})$ and the liquid was again decanted. The solid was purified by flash column chromatography $\left(\mathrm{SiO}_{2}\right)$, eluting with chloroform, to provide a red-orange solid $(0.461 \mathrm{~g}, 48 \%)$ : $\mathrm{mp} 261^{\circ} \mathrm{C}(\mathrm{dec})$. IR (KBr) 1703, 1668, 1611, 1559, 1500, $1478,1338,1299$, and $1230 \mathrm{~cm}^{-1}$; ${ }_{1} \mathrm{H}$ NMR (DMSO- $\left.d_{6}\right) \delta 8.86(\mathrm{~d}, J=2.4 \mathrm{~Hz}, 1 \mathrm{H}), 8.67$ (d, $J=9.2 \mathrm{~Hz}, 1 \mathrm{H}), 8.55(\mathrm{dd}, J=9.0 \mathrm{~Hz}$ and $2.5 \mathrm{~Hz}, 1 \mathrm{H}), 7.86(\mathrm{~d}, J=8.6 \mathrm{~Hz}, 1 \mathrm{H}), 7.21(\mathrm{~d}, J=$ $2.6 \mathrm{~Hz}, 1 \mathrm{H}), 7.11(\mathrm{dd}, J=8.6 \mathrm{~Hz}$ and $2.4 \mathrm{~Hz}, 1 \mathrm{H}), 4.63(\mathrm{~m}, 2 \mathrm{H}), 3.90(\mathrm{~s}, 3 \mathrm{H}), 3.87(\mathrm{t}, J=$ $6.6 \mathrm{~Hz}, 2 \mathrm{H}), 2.29$ (m, $2 \mathrm{H})$; MALDIMS $\mathrm{m} / z$ (rel intensity) 399/401 $\left(\mathrm{MH}^{+}, 100 / 41\right)$. Anal. $\left(\mathrm{C}_{20} \mathrm{H}_{15} \mathrm{ClN}_{2} \mathrm{O}_{5}\right) \mathrm{C}, \mathrm{H}, \mathrm{N}$. 


\section{6-(3-Chloropropyl)-5,6-dihydro-7-methoxy-3-nitro-5,11-dioxo-11H-indeno[1,2-c]isoquinoline} (28)

Thionyl chloride ( $3 \mathrm{~mL}$ ) was added to a solution of $\mathrm{cis}$-4-carboxy- $N$-(3-chloropropyl)-3,4dihydro-3-(2-methoxyphenyl)-7-nitro-1(2H)isoquinolone (23) $(1.000 \mathrm{~g}, 2.388 \mathrm{mmol})$ in benzene $(50 \mathrm{~mL})$. The reaction mixture was heated at reflux for $30 \mathrm{~min}$, allowed to cool to room temperature, and concentrated. The residue was diluted with nitrobenzene $(20 \mathrm{~mL})$, chilled in an ice bath, and aluminum chloride $(0.637 \mathrm{~g}, 4.775 \mathrm{mmol})$ was added. The reaction mixture was removed from the bath and heated at $100{ }^{\circ} \mathrm{C}$ for $1 \mathrm{~h}$. Water $(100 \mathrm{~mL})$ was added and the solution was extracted with $\mathrm{CHCl}_{3}(4 \times 75 \mathrm{~mL})$. The combined organic layer was washed with sat aq $\mathrm{NaHCO}_{3}(3 \times 50 \mathrm{~mL})$, sat aq $\mathrm{NaCl}(50 \mathrm{~mL})$, and dried over sodium sulfate. The solution was concentrated, hexanes $(250 \mathrm{~mL})$ were added, and the liquid was decanted. The solid was washed with hexanes $(100 \mathrm{~mL})$ and the liquid was again decanted. The solid was purified by flash column chromatography $\left(\mathrm{SiO}_{2}\right)$, eluting with chloroform, to provide an orange solid $(0.238 \mathrm{~g}, 25 \%)$ : $\mathrm{mp} 221-222^{\circ} \mathrm{C}$. IR (KBr) 1666, 1611, 1546, 1496, 1334, 1270 , and $760 \mathrm{~cm}^{-1} ;{ }^{1} \mathrm{H}$ NMR (DMSO- $\left.d_{6}\right) \delta 8.87(\mathrm{~d}, J=2.5 \mathrm{~Hz}, 1 \mathrm{H}), 8.79(\mathrm{~d}, J=9.0 \mathrm{~Hz}, 1 \mathrm{H}), 8.56$ $(\mathrm{dd}, J=9.0 \mathrm{~Hz}$ and $2.5 \mathrm{~Hz}, 1 \mathrm{H}), 7.61(\mathrm{dd}, J=8.5 \mathrm{~Hz}$ and $6.8 \mathrm{~Hz}, 1 \mathrm{H}), 7.46(\mathrm{~d}, J=8.5 \mathrm{~Hz}, 1$ H), $7.32(\mathrm{~d}, J=6.6 \mathrm{~Hz}, 1 \mathrm{H}), 4.75(\mathrm{t}, J=6.8 \mathrm{~Hz}, 2 \mathrm{H}), 4.04(\mathrm{~s}, 3 \mathrm{H}), 3.79(\mathrm{t}, J=6.5 \mathrm{~Hz}, 2 \mathrm{H})$, 2.28 (m, $2 \mathrm{H}$ ); MALDIMS $m / z$ (rel intensity) $398 / 400\left(\mathrm{MH}^{+}, 22 / 8\right)$. Anal. $\left(\mathrm{C}_{20} \mathrm{H}_{15} \mathrm{ClN}_{2} \mathrm{O}_{5}\right) \mathrm{C}$, $\mathrm{H}, \mathrm{N}$.

\section{6-(3-Azidopropyl)-5,6-dihydro-7,8,9-trimethoxy-3-nitro-5,11-dioxo-11 $H$-indeno[1,2-c] isoquinoline (29)}

Sodium azide (0.103 g, $1.591 \mathrm{mmol})$ and 6-(3-bromopropyl)-5,6-dihydro-7,8,9-trimethoxy-3nitro-5,11-dioxo-11H-indeno[1,2-c] isoquinoline (24) $(0.267 \mathrm{~g}, 0.530 \mathrm{mmol})$ were diluted with DMSO $(30 \mathrm{~mL})$ and the mixture was heated at $100{ }^{\circ} \mathrm{C}$ for $1.5 \mathrm{~h}$. The reaction mixture was diluted with $\mathrm{CHCl}_{3}(150 \mathrm{~mL})$, washed with water $(4 \times 30 \mathrm{~mL})$, sat aq $\mathrm{NaCl}(30 \mathrm{~mL})$, and dried over sodium sulfate. The solution was concentrated to provide a crude solid that was purified by flash column chromatography $\left(\mathrm{SiO}_{2}\right)$, eluting with chloroform, to afford a red solid (0.160 g, 65\%): mp 179-180 ${ }^{\circ} \mathrm{C}$. IR (film) 2097, 1701, 1668, 1612, 1548, 1493, 1464, 1416, 1333, and $1148 \mathrm{~cm}^{-1} ;{ }^{1} \mathrm{H}$ NMR (DMSO- $\left.d_{6}\right) \delta 8.85(\mathrm{~d}, J=2.5 \mathrm{~Hz}, 1 \mathrm{H}), 8.73(\mathrm{~d}, J=9.0 \mathrm{~Hz}, 1 \mathrm{H})$, $8.55(\mathrm{dd}, J=9.0 \mathrm{~Hz}$ and $2.5 \mathrm{~Hz}, 1 \mathrm{H}), 7.21(\mathrm{~s}, 1 \mathrm{H}), 4.75(\mathrm{t}, J=6.4 \mathrm{~Hz}, 2 \mathrm{H}), 3.97(\mathrm{~s}, 3 \mathrm{H})$, 3.96 (s, $3 \mathrm{H}), 3.85$ (s, $3 \mathrm{H}), 3.46$ (t, $J=6.7 \mathrm{~Hz}, 2 \mathrm{H}), 2.03$ (pent, $J=7.4 \mathrm{~Hz}, 2 \mathrm{H}$ ); MALDIMS $\mathrm{m} / z$ (rel intensity) $465\left(\mathrm{MH}^{+}, 56\right), 450\left(\mathrm{MH}^{+}-\mathrm{CH}_{3}, 100\right)$. Anal. $\left(\mathrm{C}_{22} \mathrm{H}_{19} \mathrm{~N}_{5} \mathrm{O}_{7}\right) \mathrm{C}, \mathrm{H}, \mathrm{N}$.

\section{6-(3-Azidopropyl)-5,6-dihydro-8,9-dimethoxy-3-nitro-5,11-dioxo-11 $\mathrm{H}$-indeno[1,2-c] isoquinoline (30)}

Procedure 1: Sodium azide $(0.103 \mathrm{~g}, 1.585 \mathrm{mmol})$ and 6-(3-bromopropyl)-5,6-dihydro-8,9dimethoxy-3-nitro-5,11-dioxo-11H-indeno[1,2-c]isoquinoline (25) $(0.250 \mathrm{~g}, 0.528 \mathrm{mmol})$ were diluted with DMSO $(40 \mathrm{~mL})$ and the mixture was allowed to stir at room temperature for $16 \mathrm{~h}$. The reaction mixture was diluted with $\mathrm{CHCl}_{3}(300 \mathrm{~mL})$, washed with water $(3 \times 50 \mathrm{~mL})$, sat aq $\mathrm{NaCl}(50 \mathrm{~mL})$, and dried over sodium sulfate. The solution was concentrated to provide a crude solid that was purified by flash column chromatography $\left(\mathrm{SiO}_{2}\right)$, eluting with chloroform, to afford a purple solid (0.162 g, 80\%): $\mathrm{mp} 240{ }^{\circ} \mathrm{C}$ (dec). IR (film) 2096, 1691, $1672,1613,1553,1507,1490,1330,1301$, and $1003 \mathrm{~cm}^{-1} ;{ }^{1} \mathrm{H}$ NMR (DMSO- $\left.d_{6}\right) \delta 8.80(\mathrm{~d}$, $J=2.3 \mathrm{~Hz}, 1 \mathrm{H}), 8.58(\mathrm{~d}, J=8.8 \mathrm{~Hz}, 1 \mathrm{H}), 8.49(\mathrm{dd}, J=8.9 \mathrm{~Hz}$ and $2.3 \mathrm{~Hz}, 1 \mathrm{H}), 7.29(\mathrm{~s}, 1$ H), $7.22(\mathrm{~s}, 1 \mathrm{H}), 4.57(\mathrm{t}, J=7.9 \mathrm{~Hz}, 2 \mathrm{H}), 3.97(\mathrm{~s}, 3 \mathrm{H}), 3.89(\mathrm{~s}, 3 \mathrm{H}), 3.70(\mathrm{t}, J=6.3 \mathrm{~Hz}, 2$ $\mathrm{H}), 2.09(\mathrm{~m}, 2 \mathrm{H})$. Anal. $\left(\mathrm{C}_{21} \mathrm{H}_{17} \mathrm{~N}_{5} \mathrm{O}_{6} \cdot 0.5 \mathrm{H}_{2} \mathrm{O}\right) \mathrm{C}, \mathrm{H}, \mathrm{N}$. Procedure 2: Sodium azide (0.108 g, $1.660 \mathrm{mmol}$ ) and cis-6-(3-bromopropyl)-5,6,12,13-tetrahydro-8,9-dimethoxy-3-nitro-5,11dioxo-11 $H$-indeno[1,2-c] isoquinoline $(\mathbf{4 0})(0.263 \mathrm{~g}, 0.553 \mathrm{mmol})$ were diluted with DMSO $(25 \mathrm{~mL})$ and allowed to stir at room temperature for $16 \mathrm{~h}$. The reaction mixture was diluted with $\mathrm{CHCl}_{3}(150 \mathrm{~mL})$, washed with water $(3 \times 25 \mathrm{~mL})$, sat aq $\mathrm{NaCl}(25 \mathrm{~mL})$, and dried over 
sodium sulfate. The solution was concentrated to provide a crude solid that was purified by flash column chromatography $\left(\mathrm{SiO}_{2}\right)$, eluting with chloroform, to afford a purple solid $(0.162$ $\mathrm{g}, 67 \%$ ) identical in all respects to the material isolated using Procedure 1.

\section{6-(3-Azidopropyl)-5,6-dihydro-7,8-dimethoxy-3-nitro-5,11-dioxo-11 $H$-indeno[1,2-c] isoquinoline (31)}

Sodium azide (0.054 g, $0.837 \mathrm{mmol})$ and 6-(3-bromopropyl)-5,6-dihydro-7,8-dimethoxy-3nitro-5,11-dioxo-11 $\mathrm{H}$-indeno[1,2-c] isoquinoline (26) $(0.132 \mathrm{~g}, 0.279 \mathrm{mmol})$ were diluted with $\operatorname{DMSO}(20 \mathrm{~mL})$ and the mixture was allowed to stir at room temperature for $16 \mathrm{~h}$. The reaction mixture was diluted with $\mathrm{CHCl}_{3}(150 \mathrm{~mL})$, washed with water $(3 \times 25 \mathrm{~mL}), 1 \mathrm{~N} \mathrm{NaOH}(4 \times$ $25 \mathrm{~mL})$, sat aq $\mathrm{NaCl}(25 \mathrm{~mL})$, and dried over sodium sulfate. The solution was concentrated to obtain a crude solid that was purified by flash column chromatography $\left(\mathrm{SiO}_{2}\right)$, eluting with $1 \%$ methanol in chloroform, to afford a yellow-orange solid $(0.050 \mathrm{~g}, 41 \%): \mathrm{mp} 210{ }^{\circ} \mathrm{C}(\mathrm{dec})$. IR (film) 2101, 1663, 1551, 1339, 1040, and $754 \mathrm{~cm}^{-1} ;{ }^{1} \mathrm{H}$ NMR (DMSO- $\left.d_{6}\right) \delta 8.90(\mathrm{~d}, J=$ $2.4 \mathrm{~Hz}, 1 \mathrm{H}), 8.86(\mathrm{~d}, J=9.2 \mathrm{~Hz}, 1 \mathrm{H}), 8.59(\mathrm{dd}, J=9.0 \mathrm{~Hz}$ and $2.5 \mathrm{~Hz}, 1 \mathrm{H}), 7.47(\mathrm{~d}, J=7.9$ $\mathrm{Hz}, 1 \mathrm{H}), 7.20(\mathrm{~d}, J=8.0 \mathrm{~Hz}, 1 \mathrm{H}), 4.77(\mathrm{t}, J=7.0 \mathrm{~Hz}, 2 \mathrm{H}), 3.95(\mathrm{~s}, 3 \mathrm{H}), 3.92(\mathrm{~s}, 3 \mathrm{H}), 3.45$ (t, $J=6.7 \mathrm{~Hz}, 2 \mathrm{H}$ ), 2.03 (pent, $J=7.5 \mathrm{~Hz}, 2 \mathrm{H}$ ); MALDIMS $m / z$ (rel intensity) $436\left(\mathrm{MH}^{+}\right.$, 100). Anal. $\left(\mathrm{C}_{21} \mathrm{H}_{17} \mathrm{~N}_{5} \mathrm{O}_{6}\right) \mathrm{C}, \mathrm{H}, \mathrm{N}$.

\section{6-(3-Azidopropyl)-5,6-dihydro-9-methoxy-3-nitro-5,11-dioxo-11H-indeno[1,2-c]isoquinoline (32)}

Sodium azide (0.206 g, $3.175 \mathrm{mmol})$ and 6-(3-chloropropyl)-5,6-dihydro-9-methoxy-3nitro-5,11-dioxo-11H-indeno[1,2-c] isoquinoline (27) $(0.422 \mathrm{~g}, 1.058 \mathrm{mmol})$ were diluted with DMSO $(50 \mathrm{~mL})$ and the mixture was heated at $100^{\circ} \mathrm{C}$ for $1.5 \mathrm{~h}$. The reaction mixture was diluted with $\mathrm{CHCl}_{3}(175 \mathrm{~mL})$, washed with water $(4 \times 30 \mathrm{~mL})$, sat aq $\mathrm{NaCl}(30 \mathrm{~mL})$, and dried over sodium sulfate. The solution was concentrated to provide a crude solid that was purified by flash column chromatography $\left(\mathrm{SiO}_{2}\right)$, eluting with chloroform, to afford a red solid $(0.374$ g, 87\%): mp 214-217 ${ }^{\circ} \mathrm{C}$. IR (KBr) 2094, 1674, 1610, 1557, 1507, 1482, 1427, 1336, 1300 , and $1258 \mathrm{~cm}^{-1} ;{ }^{1} \mathrm{H}$ NMR (DMSO- $\left.d_{6}\right) \delta 8.85(\mathrm{~d}, J=2.4 \mathrm{~Hz}, 1 \mathrm{H}), 8.65(\mathrm{~d}, J=9.0 \mathrm{~Hz}, 1 \mathrm{H})$, $8.55(\mathrm{dd}, J=8.9 \mathrm{~Hz}$ and $2.5 \mathrm{~Hz}, 1 \mathrm{H}), 7.84(\mathrm{~d}, J=8.4 \mathrm{~Hz}, 1 \mathrm{H}), 7.20(\mathrm{~d}, J=2.5 \mathrm{~Hz}, 1 \mathrm{H}), 7.12$ (dd, $J=8.2 \mathrm{~Hz}$ and $2.4 \mathrm{~Hz}, 1 \mathrm{H}), 4.57(\mathrm{t}, J=6.4 \mathrm{~Hz}, 2 \mathrm{H}), 3.91(\mathrm{~s}, 3 \mathrm{H}), 3.66(\mathrm{t}, J=6.6 \mathrm{~Hz}, 2$ $\mathrm{H}), 2.01(\mathrm{~m}, 2 \mathrm{H})$; CIMS $\mathrm{m} / z$ (rel intensity) $406\left(\mathrm{MH}^{+}, 100\right)$. Anal. $\left(\mathrm{C}_{20} \mathrm{H}_{15} \mathrm{~N}_{5} \mathrm{O}_{5} \cdot 0.25 \mathrm{H}_{2} \mathrm{O}\right)$ $\mathrm{C}, \mathrm{H}, \mathrm{N}$.

\section{6-(3-Azidopropyl)-5,6-dihydro-7-methoxy-3-nitro-5,11-dioxo-11H-indeno[1,2-c]isoquinoline (33)}

Sodium azide $(0.150 \mathrm{~g}, 2.311 \mathrm{mmol})$ and 6-(3-chloropropyl)-5,6-dihydro-7-methoxy-3nitro-5,11-dioxo-11H-indeno[1,2-c] isoquinoline $(\mathbf{2 8})(0.838 \mathrm{~g}, 2.101 \mathrm{mmol})$ were diluted with DMSO $(150 \mathrm{~mL})$ and the mixture was heated at $100{ }^{\circ} \mathrm{C}$ for $2 \mathrm{~h}$. The reaction mixture was diluted with $\mathrm{CHCl}_{3}(400 \mathrm{~mL})$, washed with water $(3 \times 100 \mathrm{~mL})$, sat aq $\mathrm{NaCl}(100 \mathrm{~mL})$, and dried over sodium sulfate. The solution was concentrated to afford an orange-red solid that was precipitated twice from EtOAc to provide a pure orange solid $(0.241 \mathrm{~g}, 28 \%)$ : $\mathrm{mp} 222-$ $223{ }^{\circ} \mathrm{C}$. IR (film) 2101, 1612, 1548, 1338, 1331, and $764 \mathrm{~cm}^{-1} ;{ }^{1} \mathrm{H} \mathrm{NMR}\left(\mathrm{CDCl}_{3}\right) \delta 8.83(\mathrm{~d}$, $J=2.5 \mathrm{~Hz}, 1 \mathrm{H}), 8.76(\mathrm{~d}, J=9.0 \mathrm{~Hz}, 1 \mathrm{H}), 8.54(\mathrm{dd}, J=9.0 \mathrm{~Hz}$ and $2.5 \mathrm{~Hz}, 1 \mathrm{H}), 7.62(\mathrm{dd}, J$ $=8.5 \mathrm{~Hz}$ and $6.9 \mathrm{~Hz}, 1 \mathrm{H}), 7.45(\mathrm{~d}, J=7.9 \mathrm{~Hz}, 1 \mathrm{H}), 7.30(\mathrm{~d}, J=6.9 \mathrm{~Hz}, 1 \mathrm{H}), 4.69(\mathrm{t}, J=7.1$ $\mathrm{Hz}, 2 \mathrm{H}), 4.03(\mathrm{~s}, 3 \mathrm{H}), 3.52(\mathrm{t}, J=6.7 \mathrm{~Hz}, 2 \mathrm{H}), 2.05(\mathrm{~m}, 2 \mathrm{H})$; ESIMS $m / z$ (rel intensity) 406 $\left(\mathrm{MH}^{+}, 100\right)$. Anal. $\left(\mathrm{C}_{20} \mathrm{H}_{15} \mathrm{~N}_{5} \mathrm{O}_{5}\right) \mathrm{C}, \mathrm{H}, \mathrm{N}$. 


\section{6-(3-Aminopropyl)-5,6-dihydro-7,8,9-trimethoxy-3-nitro-5,11-dioxo-11H-indeno[1,2-c] isoquinoline Hydrochloride (34)}

Triethyl phosphite (0.100 $\mathrm{mL}$ ) was added to a solution of 6-(3-azidopropyl)-5,6-dihydro-7,8,9trimethoxy-3-nitro-5,11-dioxo-11H-indeno[1,2-c]isoquinoline (29) $(0.109 \mathrm{~g}, 0.234 \mathrm{mmol})$ in benzene $(30 \mathrm{~mL})$ and the reaction mixture was heated at reflux for $16 \mathrm{~h}$. The reaction mixture was allowed to cool to room temperature, $3 \mathrm{M} \mathrm{HCl}$ in methanol $(8 \mathrm{~mL})$ was added, and the reaction mixture was heated at reflux for $3 \mathrm{~h}$. The reaction mixture was allowed to cool to room temperature, filtered, and the precipitate was washed with $\mathrm{CHCl}_{3}(50 \mathrm{~mL})$ to provide a red solid (0.096 g, 86\%): $\mathrm{mp} 210^{\circ} \mathrm{C}$ (dec). IR (KBr) 3446, 2944, 1665, 1611, 1497, 1466, 1417, 1332, and $1145 \mathrm{~cm}^{-1}$; ${ }^{1} \mathrm{H}$ NMR (DMSO- $\left.d_{6}\right) \delta 8.86(\mathrm{~d}, J=2.5 \mathrm{~Hz}, 1 \mathrm{H}), 8.76(\mathrm{~d}, J=9.0 \mathrm{~Hz}, 1$ H), $8.56(\mathrm{dd}, J=9.0 \mathrm{~Hz}$ and $2.5 \mathrm{~Hz}, 1 \mathrm{H}), 7.78(\mathrm{bs}, 2 \mathrm{H}), 7.23(\mathrm{~s}, 1 \mathrm{H}), 4.68$ (t, $J=6.4 \mathrm{~Hz}, 2$ $\mathrm{H}), 4.00(\mathrm{~s}, 3 \mathrm{H}), 3.98(\mathrm{~s}, 3 \mathrm{H}), 3.87(\mathrm{~s}, 3 \mathrm{H}), 2.90(\mathrm{t}, J=7.6 \mathrm{~Hz}, 2 \mathrm{H}), 2.07(\mathrm{~m}, 2 \mathrm{H})$; ESIMS $m / z$ (rel intensity) $440\left(\mathrm{MH}^{+}, 91\right), 423\left(\mathrm{MH}^{+}-\mathrm{NH}_{3}, 100\right)$. Anal. $\left(\mathrm{C}_{22} \mathrm{H}_{22} \mathrm{ClN}_{3} \mathrm{O}_{7} \cdot 0.5 \mathrm{H}_{2} \mathrm{O}\right) \mathrm{C}$, $\mathrm{H}, \mathrm{N}$.

\section{6-(3-Aminopropyl)-5,6-dihydro-8,9-dimethoxy-3-nitro-5,11-dioxo-11 $H$-indeno[1,2-c] isoquinoline Hydrochloride (35)}

Triethyl phosphite $(0.132 \mathrm{~mL})$ was added to a solution of 6-(3-azidopropyl)-5,6-dihydro-8,9dimethoxy-3-nitro-5,11-dioxo-11H-indeno[1,2-c]isoquinoline (30) $(0.134 \mathrm{~g}, 0.308 \mathrm{mmol})$ in benzene $(20 \mathrm{~mL})$ and the reaction mixture was heated at reflux for $16 \mathrm{~h}$. The reaction mixture was allowed to cool to room temperature, $3 \mathrm{M} \mathrm{HCl}$ in methanol $(7 \mathrm{~mL})$ was added, and the reaction mixture was heated at reflux for $2 \mathrm{~h}$. The reaction mixture was allowed to cool to room temperature and filtered to provide a crude red precipitate. The solid was dissolved in warm DMSO $(20 \mathrm{~mL})$ and precipitated with acetone. The solid was filtered, washed with acetone $(100 \mathrm{~mL})$, and dried to provide a red solid $(0.119 \mathrm{~g}, 87 \%)$ : $\mathrm{mp} 260-262{ }^{\circ} \mathrm{C}(\mathrm{dec})$. IR (KBr) $3555,2935,1675,1613,1557,1490,1338,1301,1216$, and $1000 \mathrm{~cm}^{-1} ;{ }^{1} \mathrm{H}$ NMR (DMSO$\left.d_{6}\right) \delta 8.87(\mathrm{~d}, J=2.4 \mathrm{~Hz}, 1 \mathrm{H}), 8.67(\mathrm{~d}, J=8.9 \mathrm{~Hz}, 1 \mathrm{H}), 8.56(\mathrm{dd}, J=8.5 \mathrm{~Hz}$ and $1.9 \mathrm{~Hz}, 1$ H), 7.80 (bs, $2 \mathrm{H}), 7.30$ (s, $1 \mathrm{H}), 7.25(\mathrm{~s}, 1 \mathrm{H}), 4.62(\mathrm{~m}, 2 \mathrm{H}), 4.02(\mathrm{~s}, 3 \mathrm{H}), 3.92(\mathrm{~s}, 3 \mathrm{H}), 3.01$ $(\mathrm{m}, 2 \mathrm{H}), 2.17(\mathrm{~m}, 2 \mathrm{H})$; ESIMS $m / z$ (rel intensity) $410\left(\mathrm{MH}^{+}, 100\right)$. Anal. $\left(\mathrm{C}_{21} \mathrm{H}_{20} \mathrm{ClN}_{3} \mathrm{O}_{6} \cdot 1.0\right.$ $\left.\mathrm{H}_{2} \mathrm{O}\right) \mathrm{C}, \mathrm{H}, \mathrm{N}$.

\section{6-(3-Aminopropyl)-5,6-dihydro-7,8-dimethoxy-3-nitro-5,11-dioxo-11 $H$-indeno[1,2-c] isoquinoline Hydrochloride (36)}

Triethyl phosphite $(0.079 \mathrm{~mL})$ was added to a solution of 6-(3-azidopropyl)-5,6-dihydro-7,8dimethoxy-3-nitro-5,11-dioxo-11H-indeno[1,2-c]isoquinoline (31) $(0.115 \mathrm{~g}, 0.264 \mathrm{mmol})$ in benzene $(30 \mathrm{~mL})$ and the reaction mixture was heated at reflux for $16 \mathrm{~h}$. The reaction mixture was allowed to cool to room temperature, $3 \mathrm{M} \mathrm{HCl}$ in methanol $(8 \mathrm{~mL})$ was added, and the reaction mixture was heated at reflux for $2 \mathrm{~h}$. The reaction mixture was allowed to cool to room temperature and filtered to provide an orange solid $(0.082 \mathrm{~g}, 69 \%)$ : $\mathrm{mp} 231^{\circ} \mathrm{C}(\mathrm{dec}) . \mathrm{IR}(\mathrm{KBr})$ $3423,2841,1666,1613,1498,1473,1336$, and $1276 \mathrm{~cm}^{-1} ;{ }^{1} \mathrm{H}$ NMR (DMSO- $\left.d_{6}\right) \delta 8.89(\mathrm{~d}$, $J=2.4 \mathrm{~Hz}, 1 \mathrm{H}), 8.86(\mathrm{~d}, J=9.0 \mathrm{~Hz}, 1 \mathrm{H}), 8.60(\mathrm{dd}, J=9.0 \mathrm{~Hz}$ and $2.5 \mathrm{~Hz}, 1 \mathrm{H}), 7.83(\mathrm{bs}, 2$ H), 7.47 (d, $J=7.9 \mathrm{~Hz}, 1 \mathrm{H}), 7.20(\mathrm{~d}, J=8.0 \mathrm{~Hz}, 1 \mathrm{H}), 4.68(\mathrm{~m}, 2 \mathrm{H}), 3.96(\mathrm{~s}, 3 \mathrm{H}), 3.94(\mathrm{~s}, 3$ $\mathrm{H}), 2.86(\mathrm{~m}, 2 \mathrm{H}), 2.10(\mathrm{~m}, 2 \mathrm{H})$; ESIMS $m / z$ (rel intensity) $410\left(\mathrm{MH}^{+}, 100\right)$. Anal. $\left(\mathrm{C}_{21} \mathrm{H}_{20} \mathrm{ClN}_{3} \mathrm{O}_{6} \cdot 0.5 \mathrm{H}_{2} \mathrm{O}\right) \mathrm{C}, \mathrm{H}, \mathrm{N}$.

\section{6-(3-Aminopropyl)-5,6-dihydro-9-methoxy-3-nitro-5,11-dioxo-11 H-indeno[1,2-c]isoquinoline Hydrochloride (37)}

Triethyl phosphite $(0.2 \mathrm{~mL})$ was added to a solution of 6-(3-azidopropyl)-5,6-dihydro-9methoxy-3-nitro-5,11-dioxo-11 $H$-indeno[1,2-c]isoquinoline (32) $(0.186 \mathrm{~g}, 0.459 \mathrm{mmol})$ in benzene $(30 \mathrm{~mL})$ and the reaction mixture was heated at reflux for $16 \mathrm{~h}$. The reaction mixture was allowed to cool to room temperature, $3 \mathrm{M} \mathrm{HCl}$ in methanol $(10 \mathrm{~mL})$ was added, and the 
reaction mixture was heated at reflux for $4 \mathrm{~h}$. The reaction mixture was allowed to cool to room temperature and filtered to provide a red solid $(0.159 \mathrm{~g}, 83 \%)$ : $\mathrm{mp} 267-269^{\circ} \mathrm{C}(\mathrm{dec})$. IR $(\mathrm{KBr})$ 2923, 1678, 1611, 1557, 1505, 1479, 1432, 1334, 1305, and $1231 \mathrm{~cm}^{-1}$; ${ }^{1} \mathrm{H}$ NMR (DMSO$\left.d_{6}\right) \delta 8.87(\mathrm{~d}, J=2.4 \mathrm{~Hz}, 1 \mathrm{H}), 8.68(\mathrm{~d}, J=8.9 \mathrm{~Hz}, 1 \mathrm{H}), 8.58(\mathrm{dd}, J=9.0 \mathrm{~Hz}$ and $2.5 \mathrm{~Hz}, 1$ H), $7.84(\mathrm{bs}, 2 \mathrm{H}), 7.81(\mathrm{~d}, J=7.2 \mathrm{~Hz}, 1 \mathrm{H}), 7.23(\mathrm{~d}, J=2.4 \mathrm{~Hz}, 1 \mathrm{H}), 7.10(\mathrm{~d}, J=8.9 \mathrm{~Hz}, 1$ $\mathrm{H}), 4.56(\mathrm{~m}, 2 \mathrm{H}), 3.92(\mathrm{~s}, 3 \mathrm{H}), 3.01$ (m, $2 \mathrm{H}), 2.12$ (m, $2 \mathrm{H})$; ESIMS $\mathrm{m} / \mathrm{z}$ (rel intensity) 380 $\left(\mathrm{MH}^{+}, 88\right), 363\left(\mathrm{MH}^{+}-\mathrm{NH}_{3}, 100\right)$. Anal. $\left(\mathrm{C}_{20} \mathrm{H}_{18} \mathrm{ClN}_{3} \mathrm{O}_{5} \cdot 0.75 \mathrm{H}_{2} \mathrm{O}\right) \mathrm{C}, \mathrm{H}, \mathrm{N}$.

\section{6-(3-Aminopropyl)-5,6-dihydro-7-methoxy-3-nitro-5,11-dioxo-11 H-indeno[1,2-c]isoquinoline Hydrochloride (38)}

Triethyl phosphite $(0.255 \mathrm{~mL}$ ) was added to a solution of 6-(3-azidopropyl)-5,6-dihydro-7methoxy-3-nitro-5,11-dioxo-11 $H$-indeno[1,2-c] isoquinoline $(\mathbf{3 3})(0.241 \mathrm{~g}, 0.595 \mathrm{mmol})$ in benzene $(50 \mathrm{~mL})$ and the reaction mixture was heated at reflux for $24 \mathrm{~h}$. The reaction mixture was allowed to cool to room temperature, $3 \mathrm{M} \mathrm{HCl}$ in methanol $(15 \mathrm{~mL})$ was added, and the reaction mixture was heated at reflux for $4 \mathrm{~h}$. The reaction mixture was concentrated, diluted with diethyl ether $(100 \mathrm{~mL})$, and the precipitate was filtered, washed with a 1:1 solution of $\mathrm{CHCl}_{3}$-hexanes $(100 \mathrm{~mL})$, and hexanes $(100 \mathrm{~mL})$ to provide an orange solid $(0.209 \mathrm{~g}, 85 \%)$ : $\mathrm{mp} 260{ }^{\circ} \mathrm{C}$ (dec). IR (KBr) 3440, 1670, 1611, 1547, 1498, and $1330 \mathrm{~cm}^{-1}$; ${ }_{1}^{1} \mathrm{H}$ NMR (DMSO$\left.d_{6}\right) \delta 8.87(\mathrm{~d}, J=2.4 \mathrm{~Hz}, 1 \mathrm{H}), 8.81(\mathrm{~d}, J=9.0 \mathrm{~Hz}, 1 \mathrm{H}), 8.59(\mathrm{dd}, J=9.2 \mathrm{~Hz}$ and $2.7 \mathrm{~Hz}, 1$ H), 7.86 (bs, $2 \mathrm{H}), 7.65$ (dd, $J=8.6 \mathrm{~Hz}$ and $7.1 \mathrm{~Hz}, 1 \mathrm{H}), 7.48(\mathrm{~d}, J=8.4 \mathrm{~Hz}, 1 \mathrm{H}), 7.34$ (d, $J$ $=6.9 \mathrm{~Hz}, 1 \mathrm{H}), 4.67(\mathrm{t}, J=6.7 \mathrm{~Hz}, 2 \mathrm{H}), 4.06(\mathrm{~s}, 3 \mathrm{H}), 2.92(\mathrm{~m}, 2 \mathrm{H}), 2.14(\mathrm{~m}, 2 \mathrm{H})$; ESIMS $\mathrm{m} / z$ (rel intensity) $380\left(\mathrm{MH}^{+}, 100\right)$. Anal. $\left(\mathrm{C}_{20} \mathrm{H}_{18} \mathrm{ClN}_{3} \mathrm{O}_{5}\right) \mathrm{C}, \mathrm{H}, \mathrm{N}$.

\section{cis-6-(3-Bromopropyl)-5,6,12,13-tetrahydro-8,9,10-trimethoxy-3-nitro-5,11-dioxo-11 H- indeno[1,2-c]isoquinoline (39)}

cis- $N$-(3-Bromopropyl)-4-carboxy-3,4-dihydro-3-(3,4,5-trimethoxyphenyl)-7-nitro-1(2H) isoquinolone (16) $(0.500 \mathrm{~g}, 0.955 \mathrm{mmol})$ and $\mathrm{P}_{2} \mathrm{O}_{5}(5.000 \mathrm{~g}, \mathrm{mmol})$ were diluted with $\mathrm{CHCl}_{3}(100 \mathrm{~mL})$ and the reaction mixture was heated at reflux with vigorous stirring. After 2 $\mathrm{h}$, the reaction mixture was filtered and the filter pad was washed with $\mathrm{CHCl}_{3}(50 \mathrm{~mL})$. The filtrate was washed with sat aq $\mathrm{NaHCO}_{3}(4 \times 25 \mathrm{~mL})$, sat aq $\mathrm{NaCl}(25 \mathrm{~mL})$, and dried over $\mathrm{Na}_{2} \mathrm{SO}_{4}$. Concentration provided a crude yellow-orange solid that was purified by precipitating from $\mathrm{CHCl}_{3}$-hexanes to provide a light-orange solid $(0.312 \mathrm{~g}, 71 \%)$ : $\mathrm{mp} 78-80^{\circ} \mathrm{C}$. IR (film) 1712, 1652, 1590, 1529, 1483, 1347, 1322, 1256, 1140, and $731 \mathrm{~cm}^{-1} ;{ }^{1} \mathrm{H} \mathrm{NMR}\left(\mathrm{CDCl}_{3}\right) \delta$ $8.94(\mathrm{~d}, J=2.5 \mathrm{~Hz}, 1 \mathrm{H}), 8.33(\mathrm{dd}, J=8.6 \mathrm{~Hz}$ and $2.5 \mathrm{~Hz}, 1 \mathrm{H}), 7.97(\mathrm{~d}, J=8.6 \mathrm{~Hz}, 1 \mathrm{H}), 6.86$ (s, $1 \mathrm{H}), 5.37(\mathrm{~d}, J=7.1 \mathrm{~Hz}, 1 \mathrm{H}), 4.57(\mathrm{~m}, 1 \mathrm{H}), 4.31(\mathrm{~d}, J=7.2 \mathrm{~Hz}, 1 \mathrm{H}), 4.02(\mathrm{~s}, 3 \mathrm{H}), 4.00$ (s, $3 \mathrm{H}), 3.82(\mathrm{~s}, 3 \mathrm{H}), 3.69(\mathrm{~m}, 1 \mathrm{H}), 3.54(\mathrm{~m}, 2 \mathrm{H}), 3.02(\mathrm{~m}, 1 \mathrm{H}), 2.27$ (m, $1 \mathrm{H})$; CIMS m/z (rel intensity) 505/507 $\left(\mathrm{MH}^{+}, 58 / 58\right), 425\left(\mathrm{MH}^{+}-\mathrm{HBr}, 100\right)$. Anal. $\left(\mathrm{C}_{20} \mathrm{H}_{15} \mathrm{BrN}_{2} \mathrm{O}_{6}\right) \mathrm{C}, \mathrm{H}$, N.

\section{cis-6-(3-Bromopropyl)-5,6,12,13-tetrahydro-8,9-dimethoxy-3-nitro-5,11-dioxo-11H-indeno [1,2-c]isoquinoline (40)}

cis- $N$-(3-Bromopropyl)-4-carboxy-3,4-dihydro-3-(3,4-dimethoxyphenyl)-7-nitro-1(2H) isoquinolone (18) $(1.000 \mathrm{~g}, 2.027 \mathrm{mmol})$ and $\mathrm{P}_{2} \mathrm{O}_{5}(10.000 \mathrm{~g})$ were diluted with $\mathrm{CHCl}_{3}(125$ $\mathrm{mL}$ ) and the reaction mixture was heated at reflux with vigorous stirring. After $2 \mathrm{~h}$, the reaction mixture was filtered and the filter pad was washed with $\mathrm{CHCl}_{3}(125 \mathrm{~mL})$. The filtrate was washed with sat aq $\mathrm{NaHCO}_{3}(4 \times 50 \mathrm{~mL})$, sat aq $\mathrm{NaCl}(50 \mathrm{~mL})$, and dried over $\mathrm{Na}_{2} \mathrm{SO}_{4}$. Concentration provided a crude yellow-orange solid that was purified by precipitating from $\mathrm{CHCl}_{3}$-hexanes to provide a light-orange solid $(0.299 \mathrm{~g}, 31 \%)$ : $\mathrm{mp} 186-188^{\circ} \mathrm{C}$. IR (film) 1711 , $1651,1529,1504,1347,1304$, and $732 \mathrm{~cm}^{-1} ;{ }^{1} \mathrm{H} \mathrm{NMR}\left(\mathrm{CDCl}_{3}\right) \delta 8.95(\mathrm{~d}, J=2.5 \mathrm{~Hz}, 1 \mathrm{H})$, $8.35(\mathrm{dd}, J=8.6 \mathrm{~Hz}$ and $2.5 \mathrm{~Hz}, 1 \mathrm{H}), 7.98(\mathrm{~d}, J=9.2 \mathrm{~Hz}, 1 \mathrm{H}), 7.18(\mathrm{~s}, 1 \mathrm{H}), 7.12(\mathrm{~s}, 1 \mathrm{H})$, $5.46(\mathrm{~d}, J=7.0 \mathrm{~Hz}, 1 \mathrm{H}), 4.55(\mathrm{~m}, 1 \mathrm{H}), 4.35(\mathrm{~d}, J=7.0 \mathrm{~Hz}, 1 \mathrm{H}), 4.04(\mathrm{~s}, 3 \mathrm{H}), 3.90(\mathrm{~s}, 3 \mathrm{H})$, 
$3.74(\mathrm{~m}, 1 \mathrm{H}), 3.55(\mathrm{~m}, 2 \mathrm{H}), 2.40(\mathrm{~m}, 1 \mathrm{H}), 2.24(\mathrm{~m}, 1 \mathrm{H})$; CIMS m/z (rel intensity) 475/477 $\left(\mathrm{MH}^{+}, 50 / 44\right), 395\left(\mathrm{MH}^{+}-\mathrm{HBr}, 61\right), 365\left(\mathrm{MH}^{+}-\mathrm{HBr}-\mathrm{NO}, 100\right)$. Anal. $\left(\mathrm{C}_{20} \mathrm{H}_{15} \mathrm{BrN}_{2} \mathrm{O}_{6} \cdot 0.5\right.$ $\left.\mathrm{H}_{2} \mathrm{O}\right) \mathrm{C}, \mathrm{H}, \mathrm{N}$.

\section{6-(3-Azidopropyl)-5,6-dihydro-8,9,10-trimethoxy-3-nitro-5,11-dioxo-11 H-indeno[1,2-c] isoquinoline (41)}

Sodium azide (0.099 g, $1.526 \mathrm{mmol})$ and cis-6-(3-bromopropyl)-5,6,12,13-tetrahydro-8,9,10trimethoxy-3-nitro-5,11-dioxo-11 $H$-indeno[1,2-c]isoquinoline (39) $(0.257 \mathrm{~g}, 0.509 \mathrm{mmol})$ were diluted with DMSO $(20 \mathrm{~mL})$ and allowed to stir at room temperature for $16 \mathrm{~h}$. The reaction mixture was diluted with $\mathrm{CHCl}_{3}(180 \mathrm{~mL})$, washed with water $(3 \times 25 \mathrm{~mL})$, sat aq $\mathrm{NaCl}(25$ $\mathrm{mL}$ ), and dried over sodium sulfate. The solution was concentrated to provide a crude solid that was purified by flash column chromatography $\left(\mathrm{SiO}_{2}\right)$, eluting with chloroform, to afford a red solid $(0.105 \mathrm{~g}, 44 \%)$ : $\mathrm{mp} 180{ }^{\circ} \mathrm{C}$ (dec). IR (film) 2099, 1674, 1614, 1504, 1478, 1336, and $1257 \mathrm{~cm}^{-1} ;{ }^{1} \mathrm{H}$ NMR (DMSO- $\left.d_{6}\right) \delta 8.87(\mathrm{~s}, 1 \mathrm{H}), 8.74(\mathrm{~d}, J=9.2 \mathrm{~Hz}, 1 \mathrm{H}), 8.55(\mathrm{~d}, J=$ $9.2 \mathrm{~Hz}, 1 \mathrm{H}), 7.23(\mathrm{~s}, 1 \mathrm{H}), 4.60(\mathrm{~m}, 2 \mathrm{H}), 4.03(\mathrm{~s}, 3 \mathrm{H}), 3.96(\mathrm{~s}, 3 \mathrm{H}), 3.81(\mathrm{~s}, 3 \mathrm{H}), 3.69(\mathrm{t}, J$ $=6.2 \mathrm{~Hz}, 2 \mathrm{H}), 2.07(\mathrm{~m}, 2 \mathrm{H})$; MALDIMS $\mathrm{m} / z$ (rel intensity) $466\left(\mathrm{MH}^{+}, 100\right)$. Anal.

$\left(\mathrm{C}_{22} \mathrm{H}_{19} \mathrm{~N}_{5} \mathrm{O}_{7}\right) \mathrm{C}, \mathrm{H}, \mathrm{N}$.

\section{6-(3-Aminopropyl)-5,6-dihydro-8,9,10-trimethoxy-3-nitro-5,11-dioxo-11H-indeno[1,2-c] isoquinoline Hydrochloride (42)}

Triethyl phosphite $(0.062 \mathrm{~mL})$ was added to a solution of 6-(3-azidopropyl)-5,6dihydro-8,9,10-trimethoxy-3-nitro-5,11-dioxo-11H-indeno[1,2-c] isoquinoline (41) $(0.067 \mathrm{~g}$, $0.144 \mathrm{mmol})$ in benzene $(15 \mathrm{~mL})$ and the reaction mixture was heated at reflux for $16 \mathrm{~h}$. The reaction mixture was allowed to cool to room temperature, $3 \mathrm{M} \mathrm{HCl}$ in methanol $(5 \mathrm{~mL})$ was added, and the reaction mixture was heated at reflux for $2 \mathrm{~h}$. The reaction mixture was allowed to cool to room temperature and the solid was filtered and dried to provide a red precipitate $(0.059 \mathrm{~g}, 86 \%)$ : $\mathrm{mp} 235^{\circ} \mathrm{C}$ (dec). IR (KBr) 3459, 3255, 2945, 1691, 1662, 1615, 1563, 1505, $1477,1411,1339$, and $1137 \mathrm{~cm}^{-1},{ }^{1} \mathrm{H}$ NMR (DMSO- $\left.d_{6}\right) \delta 8.89(\mathrm{~d}, J=2.5 \mathrm{~Hz}, 1 \mathrm{H}), 8.77(\mathrm{~d}$, $J=9.1 \mathrm{~Hz}, 1 \mathrm{H}), 8.58(\mathrm{dd}, J=9.0 \mathrm{~Hz}$ and $2.5 \mathrm{~Hz}, 1 \mathrm{H}), 7.58(\mathrm{bs}, 2 \mathrm{H}), 7.16(\mathrm{~s}, 1 \mathrm{H}), 4.61(\mathrm{~m}$, $2 \mathrm{H}), 4.05$ (s, $3 \mathrm{H}), 3.97$ (s, $3 \mathrm{H}), 3.82$ (s, $3 \mathrm{H}), 3.00$ (t, $J=7.0 \mathrm{~Hz}, 2 \mathrm{H}), 2.15$ (m, $2 \mathrm{H})$; ESIMS $\mathrm{m} / z$ (rel intensity) $440\left(\mathrm{MH}^{+}, 100\right)$. Anal. $\left(\mathrm{C}_{22} \mathrm{H}_{22} \mathrm{ClN}_{3} \mathrm{O}_{7} \cdot 0.75 \mathrm{H}_{2} \mathrm{O}\right) \mathrm{C}, \mathrm{H}, \mathrm{N}$.

\section{Topoisomerase I-Mediated DNA Cleavage Reactions}

Human recombinant Top1 was purified from Baculovirus as described previously. ${ }^{37}$ The 161 bp fragment from pBluescript SK(-) phagemid DNA (Stratagene, La Jolla, CA) was cleaved with the restriction endonuclease Pvu II and Hind III (New England Biolabs, Beverly, MA) in supplied NE buffer $2\left(50 \mu \mathrm{L}\right.$ reactions) for $1 \mathrm{~h}$ at $37^{\circ} \mathrm{C}$, and separated by electrophoresis in a $1 \%$ agarose gel made in $1 \times \mathrm{TBE}$ buffer. The $161 \mathrm{bp}$ fragment was eluted from the gel slice using the QIAEX II kit (QIAGEN Inc., Valencia, CA). Approximately $200 \mathrm{ng}$ of the fragament was 3 '-end labeled at the Hind III site by fill-in reaction with [alpha- ${ }^{32} \mathrm{P}$ ]-dGTP and $0.5 \mathrm{mM}$ dATP, dCTP, and dTTP, in React 2 buffer ( $50 \mathrm{mM}$ Tris- $\mathrm{HCl}, \mathrm{pH} 8.0,100 \mathrm{mM} \mathrm{MgCl}_{2}, 50 \mathrm{mM}$ $\mathrm{NaCl}$ ) with 0.5 unit of DNA polymerase I (Klenow fragment). Unincorporated ${ }^{32} \mathrm{P}$-dGTP was removed using mini Quick Spin DNA columns (Roche, Indianapolis, IN), and the eluate containing the $3^{\prime}$-end-labeled $161 \mathrm{bp}$ fragment was collected. Aliquots (approximately 50,000 $\mathrm{dpm} /$ reaction) were incubated with topoisomerase I at $22{ }^{\circ} \mathrm{C}$ for $30 \mathrm{~min}$ in the presence of the tested drug. Reactions were terminated by adding SDS ( $0.5 \%$ final concentration). The samples $(10 \mu \mathrm{L}$ ) were mixed with $30 \mu \mathrm{L}$ of loading buffer ( $80 \%$ formamide, $10 \mathrm{mM}$ sodium hydroxide, $1 \mathrm{mM}$ sodium EDTA, $0.1 \%$ xylene cyanol, and $0.1 \%$ bromophenol blue, $\mathrm{pH}$ 8.0). Aliquots were separated in denaturing gels ( $16 \%$ polyacrylamine, $7 \mathrm{M}$ urea). Gels were dried and visualized by using a Phosphoimager and ImageQuant software (Molecular Dynamics, Sunnyvale, CA). 


\section{Molecular Modeling}

The structure of the ternary complex, containing topoisomerase I, DNA, and an indenoisoquinoline, was downloaded from the Protein Data Bank (PDB code 1SC7). ${ }^{11}$ Several of the atoms were then fixed according to the Syby ${ }^{\circledR}$ atom types. Hydrogens were added and minimized using the MMFF94s force field and MMFF94 charges. Modeled analogues were constructed in Sybyl ${ }^{\circledR}$, energy minimized with the MMFF94s force field and MMFF94 charges, overlapped with the crystal structure ligand in the ternary complex, and the crystal structure ligand was then deleted. The new complex was subsequently subjected to energy minimization using MMFF94s force field with MMFF94 charges. During the energy minimization, the structure of the indenoisoquinoline was allowed to move, while the structures of the protein and nucleic acids were frozen. The energy minimization was performed using the Powell method with a $0.05 \mathrm{kcal} / \mathrm{mol}$ A energy gradient convergence criterion and a distance-dependent dielectric function. Additional models (See Supporting Information) were developed using a similar procedure from a ternary complex containing topoisomerase I, DNA, and topotecan (PDB code $1 \mathrm{~K} 4 \mathrm{~T}$ ). ${ }^{10}$ Molecular surfaces were created using the MOLCAD module implemented in Sybyl ${ }^{\circledR} 6.9$ and Sybyl ${ }^{\circledR} 7.1$ with MMFF94 charges.

\section{Supplementary Material}

Refer to Web version on PubMed Central for supplementary material.

\section{Acknowledgements}

This work was made possible by the National Institutes of Health (NIH) through support of this work with Research Grant UO1 CA89566, Training Grant ST32 CA09634-12, and by an ACS Medicinal Chemistry Pre-doctoral Fellowship sponsored by Pfizer Global Research and Development (A.M.). The in vitro and in vivo testing was conducted through the Developmental Therapeutics Program, DCTD, NCI under Contract NO1-CO-56000. This research was supported in part by the Intramural Research Program of the NIH, National Cancer Institute, Center for Cancer Research.

\section{References}

1. Kohlhagen G, Paull KD, Cushman M, Nagafuji P, Pommier Y. Protein-Linked DNA Strand Breaks Induced by NSC 314622, a Novel Noncamptothecin Topoisomerase I Poison. Mol Pharmacol 1988;54:50-58. [PubMed: 9658189]

2. Antony S, Jayaraman M, Laco G, Kohlhagen G, Kohn KW, Cushman M, Pommier Y. Differential Induction of Topoisomerase I-DNA Cleavage Complexes by the Indenoisoquinoline MJ-III-65 (NSC 706744) and Camptothecin: Base Sequence Analysis and Activity against Camptothecin-Resistant Topoisomerase I. Cancer Res 2003;63:7428-7435. [PubMed: 14612542]

3. Antony S, Kohlhagen G, Agama K, Jayaraman M, Cao S, Durrani FA, Rustum YM, Cushman M, Pommier Y. Cellular Topoisomerase I Inhibition and Antiproliferative Activity by MJ-III-65 (NSC 706744), an Indenoisoquinoline Topoisomerase I Poison. Mol Pharmacol 2005;67:523-530. [PubMed: 15531731]

4. Wall ME, Wani MC, Cook CE, Palmer KH, McPhall AT, Sim GA. The Isolation and Structure of Camptothecin, a Novel Alkaloidal Leukemia and Tumor Inhibitor from Camptotheca acuminata. J Am Chem Soc 1966;88:3888-3890.

5. Hsiang YH, Hertzberg R, Hecht S, Liu LF. Camptothecin Induces Protein-Linked DNA Breaks via Mammalian DNA Topoisomerase I. J Biol Chem 1985;260:14873-14878. [PubMed: 2997227]

6. Nitiss JL, Wang JC. DNA Topoisomerase-Targeting Antitumor Drugs can be Studied in Yeast. Proc Natl Acad Sci USA 1988;85:7501-7505. [PubMed: 2845409]

7. Bjornski MA, Benedetti P, Viglianti GA, Wang JC. Expression of Human DNA Topoisomerase I in Yeast Cells Lacking Yeast DNA Topoisomerase I: Restoration of Sensitivity of the Cells to the Antitumor Drug Camptothecin. Cancer Res 1989;49:6318-6323. [PubMed: 2553253] 
8. Pommier Y, Kohlhagen G, Kohn KW, Leteurtre F, Wani MC, Wall ME. Interaction of an Alkylating Camptothecin Derivative with a DNA Base at Topoisomerase I-DNA Cleavage Sites. Proc Natl Acad Aci USA 1995;92:8861-8865.

9. Pommier Y, Pourquier P, Fan Y, Strumberg D. Mechanism of Action of Eukaryotic DNA Topoisomerase I and Drugs Targeted to the Enzyme. Biochem Biophys Acta 1998;1400:83-106. [PubMed: 9748515]

10. Staker BL, Hjerrild K, Feese MD, Behnke CA, Burgin AB Jr, Stewart L. The Mechanism of Topoisomerase I Poisoning by a Camptothecin Analog. Proc Natl Acad Sci USA 2002;99:1538715392. [PubMed: 12426403]

11. Staker BL, Feese MD, Cushman M, Pommier Y, Zembower D, Stewart L, Burgin AB. Structures of Three Classes of Anticancer Agents Bound to the Human Topoisomerase I-DNA Covalent Complex. J Med Chem 2005;48:2336-2345. [PubMed: 15801827]

12. Ioanoviciu A, Antony S, Pommier Y, Staker BL, Stewart L, Cushman M. Synthesis and Mechanism of Action Studies of a Series of Norindenoisoquinoline Topoisomerase I Poisons Reveal and Inhibitor with a Flipped Orientation in the Ternary DNA-Enzyme-Inhibitor Complex As Determined by Xray Crystallographic Analysis. J Med Chem 2005;48:4803-4814. [PubMed: 16033260]

13. Marchand C, Antony S, Kohn KW, Cushman M, Ioanoviciu A, Staker BL, Burgin AB, Stewart L, Pommier Y. A Novel Norindenoisoquinoline Structure Reveals a Common Interfacial Inhibitor Paradigm for Ternary Trapping of the Topoisomerase I-DNA Covalent Complex. Mol Cancer Ther 2006;5:287-295. [PubMed: 16505102]

14. Chen AY, Liu LF. DNA Topoisomerases: Essential Enzymes and Lethal Targets. Rev Pharmacol Toxicol 1994;34:191-218.

15. Strumber D, Pommier Y, Paull K, Jayaraman M, Nagafuji P, Cushman M. Synthesis of Cytotoxic Indenoisoquinoline Topoisomerase I Poisons. J Med Chem 1999;42:446-457. [PubMed: 9986716]

16. Cushman M, Jayaraman M, Vroman JA, Fukunaga AK, Fox BM, Kohlhagen G, Strumberg D, Pommier Y. Synthesis of New Indeno[1,2-c]isoquinolines: Cytotoxic Non-Camptothecin Topoisomerase I Inhibitors. J Med Chem 2000;43:3688-3698. [PubMed: 11020283]

17. Jayaraman M, Fox BM, Hollingshead M, Kohlhagen G, Pommier Y, Cushman M. Synthesis of New Dihydroindeno[1,2-c]isoquinoline and Indenoisoquinolinium Chloride Topoisomerase I Inhibitors Having High in Vivo Anticancer Acitivity in the Hollow Fiber Animal Model. J Med Chem 2002;45:242-249. [PubMed: 11754595]

18. Fox BM, Xiao X, Antony S, Kohlhagen G, Pommier Y, Staker BL, Stewart L, Cushman M. Design, Synthesis, and Biological Evaluation of Cytotoxic 11-Alkenylindenoisoquinoline Topoisomerase I Inhibitors and Indenoisoquinoline-Camptothecin Hybrids. J Med Chem 2003;46:3275-3282. [PubMed: 12852757]

19. Nagarajan M, Xiao X, Antony S, Kohlhagen G, Pommier Y, Cushman M. Design, Synthesis, and Biological Evaluation of Indenoisoquinoline Topoisomerase I Inhibitors Featuring Polyamine Side Chains on the Lactam Nitrogen. J Med Chem 2003;46:5712-5724. [PubMed: 14667224]

20. Nagarajan M, Morrell A, Fort BC, Meckley MR, Antony S, Kohlhagen G, Pommier Y, Cushman M. Synthesis and Anticancer Activity of Simplified Indenoisoquinoline Topoisomerase I Inhibitors Lacking Substituents on the Aromatic Rings. J Med Chem 2004;47:5651-5661. [PubMed: 15509164]

21. Xiao X, Antony S, Kohlhagen G, Pommier Y, Cushman M. Design, Synthesis, and Biological Evaluation of Cytotoxic 11-Aminoalkenylindenoisoquinoline and 11-

Diaminoalkenylindenoisoquinoline Topoisomerase I Inhibitors. Bioorg Med Chem 2004;12:51475160. [PubMed: 15351398]

22. Morrell A, Antony S, Kohlhagen G, Pommier Y, Cushman M. Synthesis of Benz $[d]$ indeno[1,2- $b]$ pyran-5,11-diones: Versatile Intermediates for the Design and Synthesis of Topoisomerase I Inhibitors. Bioorg Med Chem Lett 2006;16:1846-1849. [PubMed: 16442283]

23. Cushman M, Cheng L. Stereoselective Oxidation by Thionyl Chloride Leading to the Indeno[1,2-c] isoquinoline System. J Org Chem 1978;43:3781-3783.

24. Morrell A, Antony S, Kohlhagen G, Pommier Y, Cushman M. Synthesis of Nitrated Indenoisoquinolines as Topoisomerase I Inhibitors. Bioorg Med Chem Lett 2004;14:3659-3663. [PubMed: 15203138] 
25. Xiao X, Cushman M. An Ab Initio Quantum Mechanics Calculation that Correlates with Ligand Orientation and DNA Cleavage Site Selectivity in Camptothecin-DNA-Topoisomerase I Ternary Cleavage Complexes. J Am Chem Soc 2005;127:9960-9961. [PubMed: 16011334]

26. Xiao X, Cushman M. Effect of E-Ring Modifications in Camptothecin on Topoisomerase I Inhibition: A Quantum Mechanics Treatment. J Org Chem 2005;70:9584-9587. [PubMed: 16268636]

27. Xiao X, Antony S, Pommier Y, Cushman M. On the Binding of Indeno[1,2-c]isoquinolines in the DNA-Topoisomerase I Cleavage Complex. J Med Chem 2005;48:3231-3238. [PubMed: 15857129]

28. Singh SK, Ruchelman AL, Li TK, Liu A, Liu LF, LaVoie EJ. Nitro and Amino Substitution in the D-Ring of 5-(2-Dimethylaminoethyl)-2,3-methylenedioxy-5H-dibenzo[ $c, h][1,6]$ napthyridin-6ones: Effect on Topoisomerase-I Targeting Activity and Cytotoxicity. J Med Chem 2003;46:22542257. [PubMed: 12747798]

29. Whitmore WF, Cooney RC. The Preparation of Homophthalyl Cyclic hydrazide and 4Aminohomophthalyl Cyclic Hydrazide. J Am Chem Soc 1944;66:1237-1240.

30. Negi AS, Chattopadhyay SK, Srivastava S, Bhattacharya AK. A Simple Regioselective Demethylation of $p$-Aryl Methyl Ethers Using Aluminum Chloride-Dichloromethane System. Synth Commun 2005;35:15-21.

31. Sudo Y, Arai S, Nishida A. Facile and Regioselective Dealkylation of Alkyl Aryl Ethers Using Niobium(V) Pentachloride. Eur J Org Chem 2006;3:752-758.

32. Xiao X, Miao ZH, Antony S, Pommier Y, Cushman M. Dihydroindenoisoquinolines Function as Prodrugs of Indenoisoquinolines. Bioorg Med Chem Lett 2005;15:2795-2798. [PubMed: 15911256]

33. Morrell A, Jayaraman M, Nagarajan M, Fox BM, Meckley MR, Ioanoviciu A, Pommier Y, Antony S, Hollingshead M, Cushman M. Evaluation of Indenoisoquinoline Topoisomerase I Inhibitors Using a Hollow Fiber Assay. Bioorg Med Chem Lett 2006;16:4395-4399. [PubMed: 16750365]

34. Jaxel C, Kohn KW, Wani MC, Wall ME, Pommier Y. Structure-Activity Study of the Actions of Camptothecin Derivatives on Mammalian Topoisomerase I: Evidence for a Specific Receptor Site and a Relation to Antitumor Activity. Cancer Res 1989;49:1465-1469. [PubMed: 2538227]

35. Fan Y, Weinstein JN, Kohn KW, Shi LM, Pommier Y. Molecular Modeling Studies of the DNATopoisomerase I Ternary Cleavable Complex with Camptothecin. J Med Chem 1998;41:2216-2226. [PubMed: 9632354]

36. Yus M, Soler T, Foubelo F. A New and Direct Synthesis of 2-Substituted Pyrrolidines. J Org Chem 2001;66:6207-6208. [PubMed: 11529756]

37. Pourquier P, Ueng LM, Fertala J, Wang D, Park HK, Essigmann JM, Bjornsti MA, Pommier Y. Induction of Reversible Complexes Between Eukaryotic DNA Topoisomerase I and DNA-containing Oxidative Base Damages. 7,8-Dihydro-8-Oxoguanine and 5-Hydroxycytosine. J Biol Chem 1999;274:8516-8523. [PubMed: 10085084] 


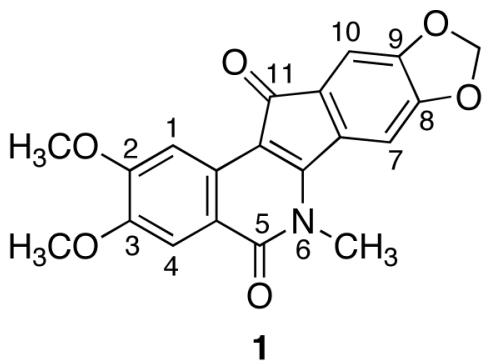

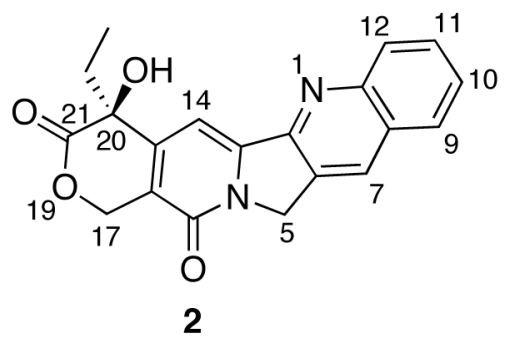<smiles>[R]CCCn1c2ccc([N+](=O)[O-])cc2c(=O)c2cc3c(cc21)OCO3</smiles><smiles>Nc1ccc2c3c(n(CCCCl)c(=O)c2c1)-c1cc2c(cc1C3=O)OCO2</smiles>

3: $\mathrm{R}=\mathrm{Cl}$

6

4: $\mathrm{R}=\mathrm{N}_{3}$

5: $\mathrm{R}=\mathrm{NH}_{2} \cdot \mathrm{HCl}$

Figure 1.

Representative Topoisomerase I Inhibitors 


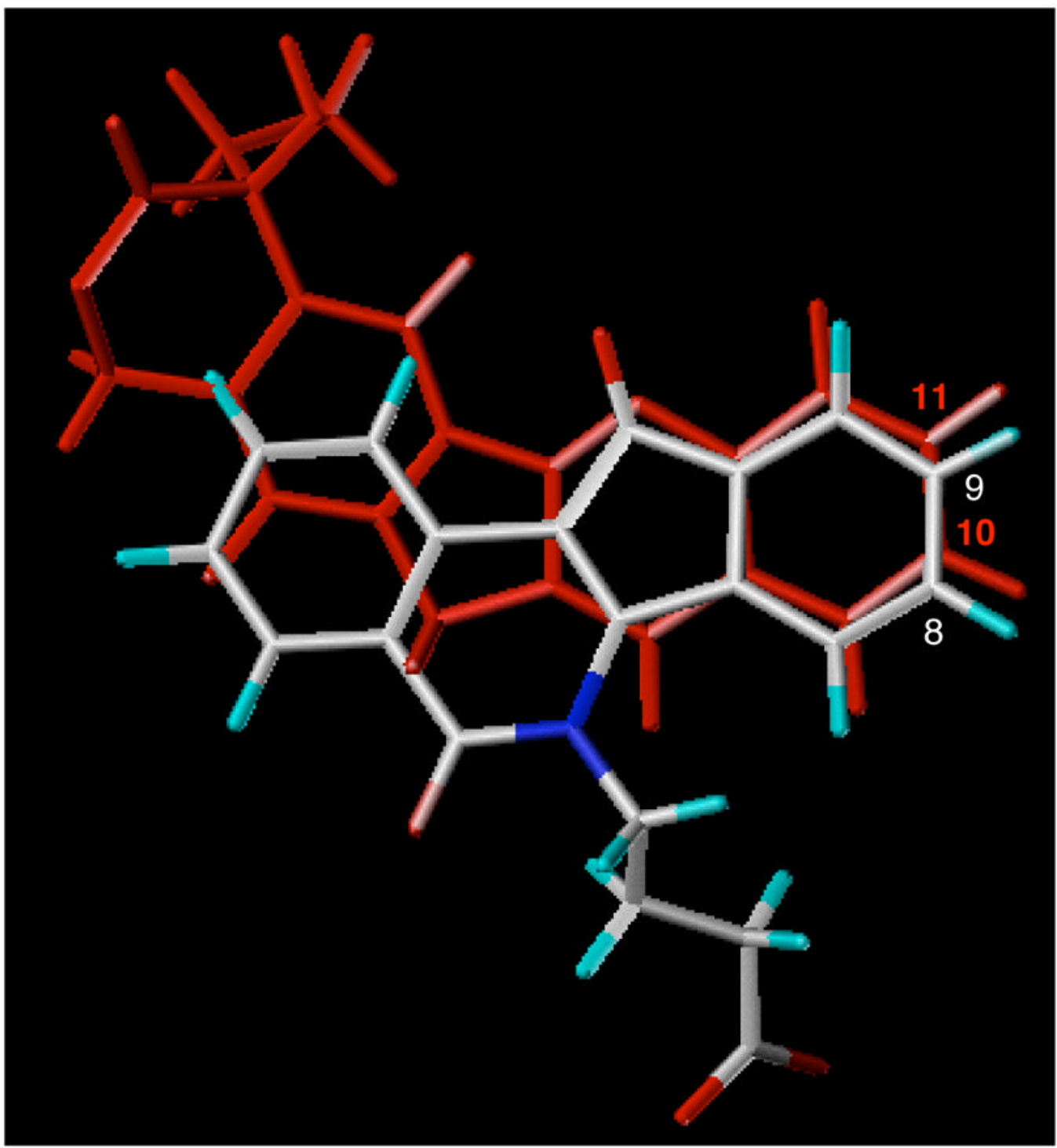

Figure 2.

Ligand overlay for the crystal structures of camptothecin (red) and an indenoisoquinoline (colored by atom type). Numbers in red correspond to camptothecin atom numbering and numbers in white correspond to indenoisoquinoline atom numbering. 


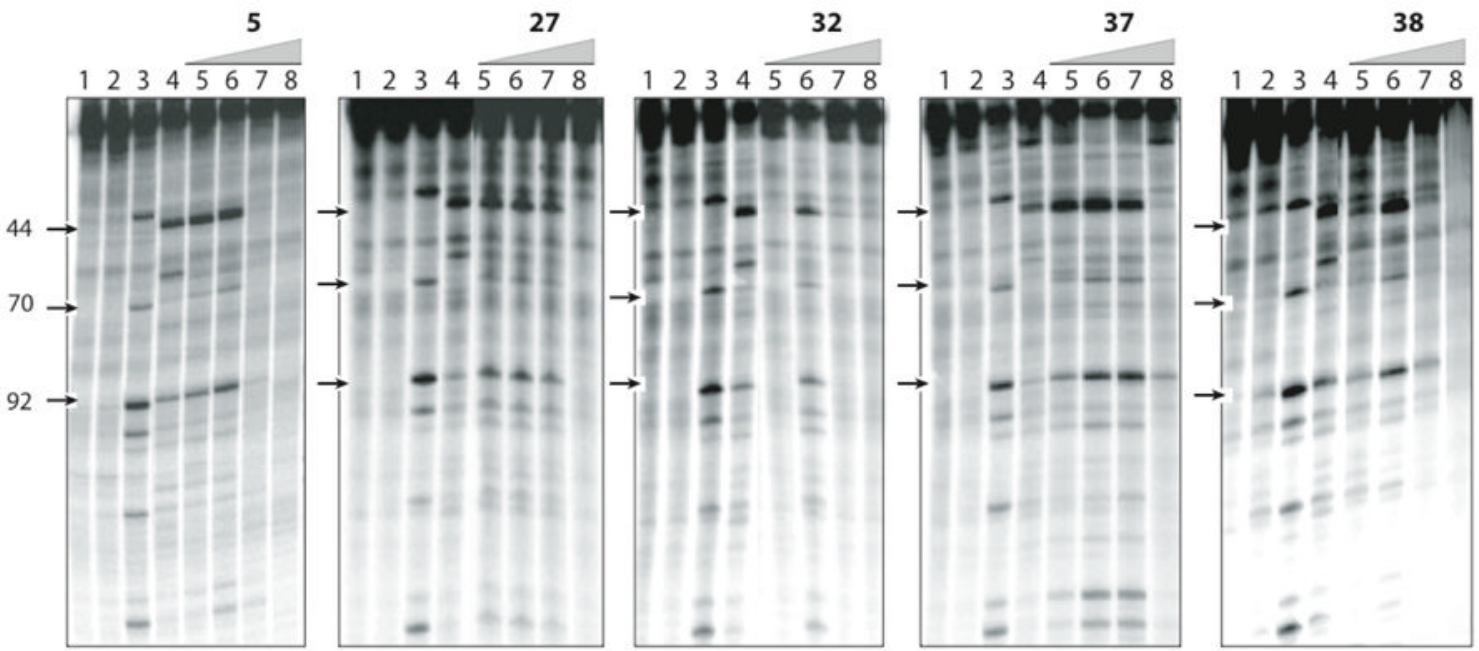

Figure 3.

Lane 1: DNA alone; lane 2: Top1 alone; lane 3: + CPT $(1 \mu \mathrm{M})$; lane 4: Top1 + MJ-III-65 (NSC 706744) (1 $\mu \mathrm{M})$; lanes 5-8: Top $1+$ indicated compound at $0.1,1,10$ and $100 \mu \mathrm{M}$, respectively). Number on left and arrows indicate cleavage site positions. 


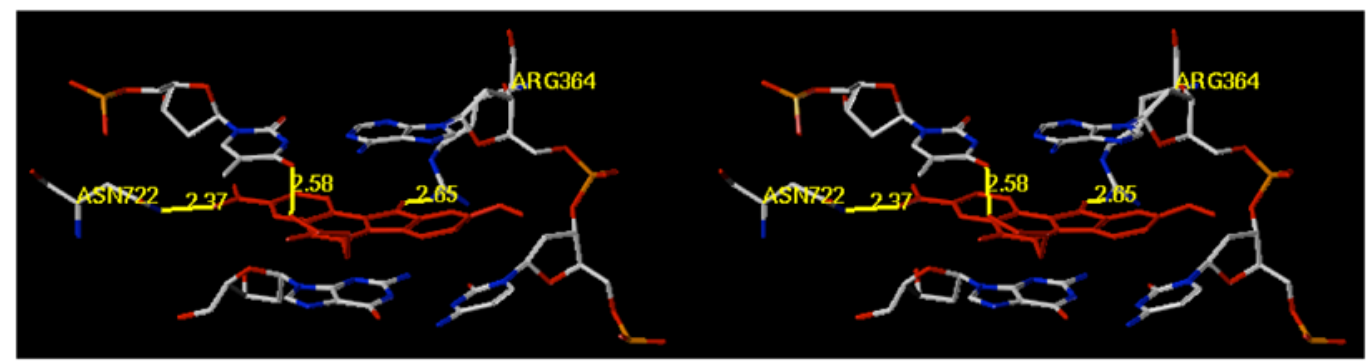

Figure 4.

Hypothetical model of compound $\mathbf{3 7}$ (red) in ternary complex with DNA and Top1. Top1 amino acid residues not involved in bonding interactions have been removed to improve clarity. The stereoview is programmed for wall-eyed (relaxed) viewing. 


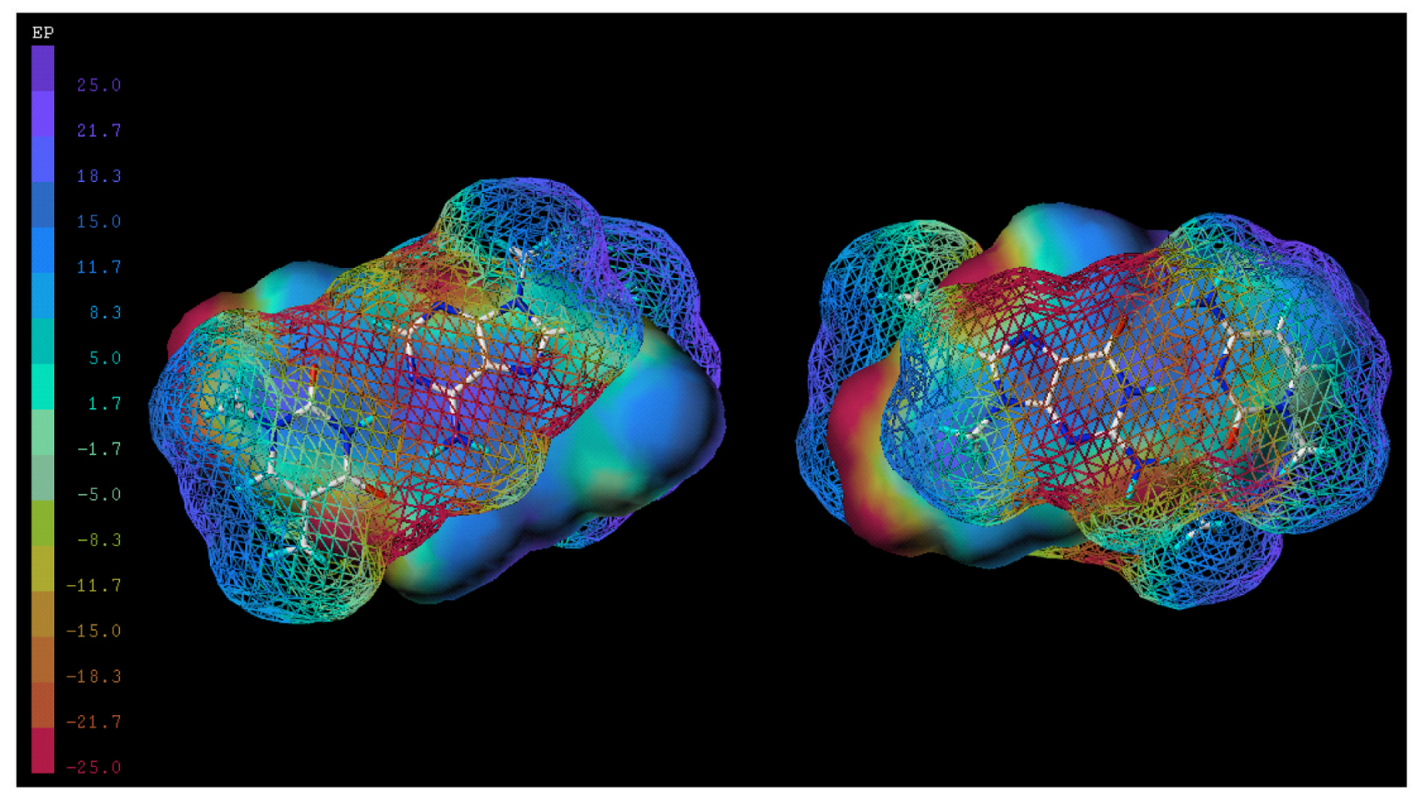

Figure 5.

Electrostatic potential surfaces for truncated analogue $\mathbf{5}$ (solid surface) intercalated between DNA base pairs (line surface). The left model is a view of the -1 base pair and the right model is a view of the +1 base pair. Red coloring indicates regions of negative charge and blue coloring indicates regions of positive charge. All generated surfaces were globally scaled to a range of $+25 \mathrm{kcal} / \mathrm{mol}$ to $-25 \mathrm{kcal} / \mathrm{mol}$ and used MMFF94 charges. 


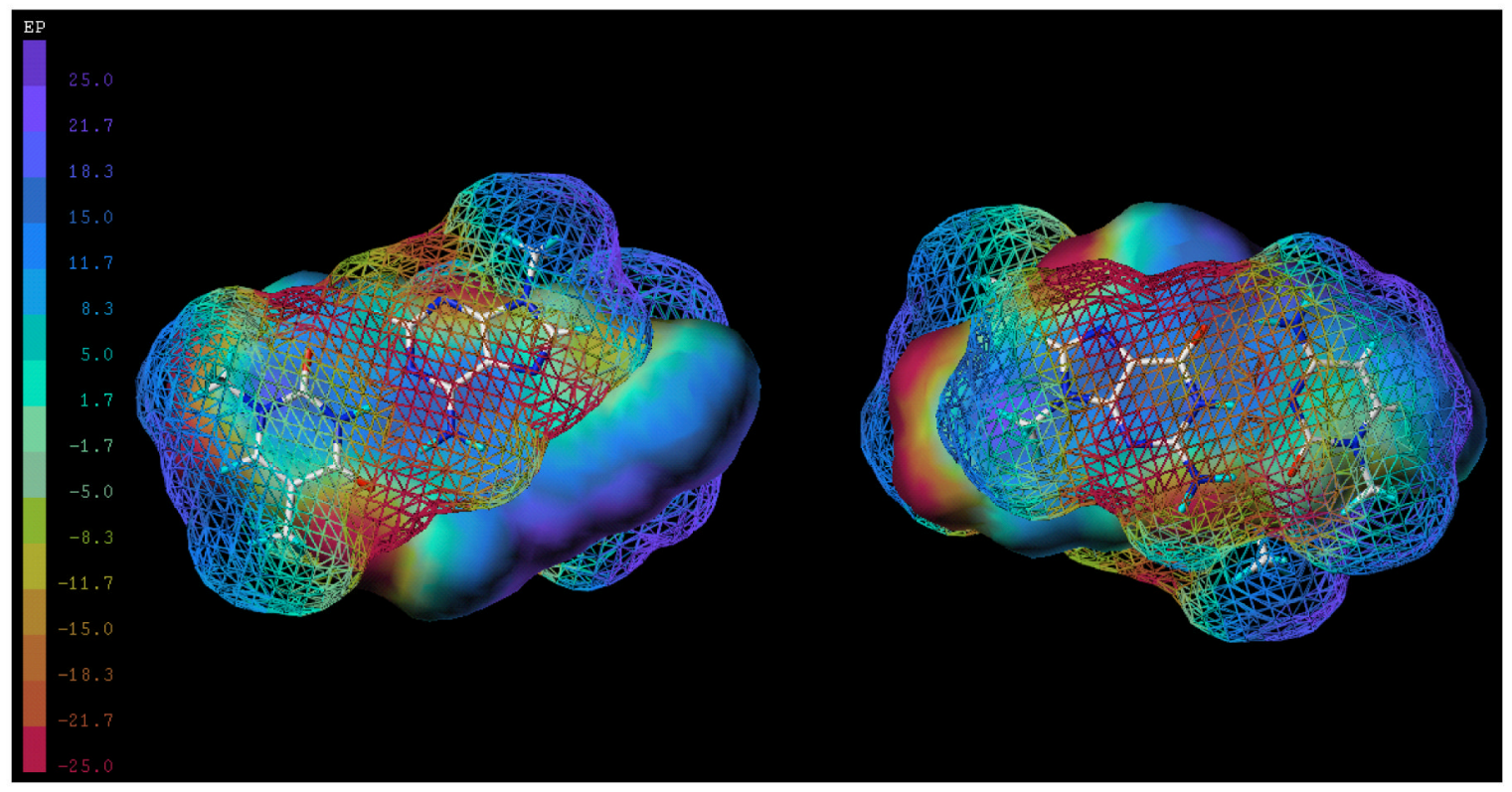

Figure 6.

Electrostatic potential surfaces for truncated analogue $\mathbf{3 7}$ (solid surface) intercalated between DNA base pairs (line surface). The left model is a view of the -1 base pair and the right model is a view of the +1 base pair. Red coloring indicates regions of negative charge and blue coloring indicates regions of positive charge. All generated surfaces were globally scaled to a range of $+25 \mathrm{kcal} / \mathrm{mol}$ to $-25 \mathrm{kcal} / \mathrm{mol}$ and used MMFF94 charges. 
<smiles>[3H]c1ccc2c(c1[N+](=O)[O-])C(=O)OC(=O)C2</smiles><smiles>[X]CCC/N=C/c1cc([R3])c([R])c([R])c1Br</smiles><smiles>[X]CCCN1C(=O)c2cc([N+](=O)[O-])ccc2C(C(=O)O)C1c1cc([R3])c([R3])c([R])c1[B]</smiles><smiles>CPC</smiles>

8: $\mathrm{R}_{1}=\mathrm{H} ; \mathrm{R}_{2}, \mathrm{R}_{3}, \mathrm{R}_{4}=\mathrm{OCH}_{3} ; \mathrm{X}=\mathrm{Br}$ 9: $\mathrm{R}_{1}, \mathrm{R}_{2}, \mathrm{R}_{3}=\mathrm{OCH}_{3} ; \mathrm{R}_{4}=\mathrm{H} ; \mathrm{X}=\mathrm{Br}$ 10: $R_{1}, R_{4}=H ; R_{2}, R_{3}=\mathrm{OCH}_{3} ; X=B r$ 11: $R_{1}, R_{2}=O_{C H} ; R_{3}, R_{4}=H ; X=B r$ 12: $R_{1}, R_{4}=O C_{3} ; R_{2}, R_{3}=H ; X=B r$ 13: $R_{1}, R_{2}, R_{4}=H, R_{3}=O_{3} \mathrm{CH}_{3} ; X=C l$ 14: $\mathrm{R}_{1}, \mathrm{R}_{3}, \mathrm{R}_{4}=\mathrm{H} ; \mathrm{R}_{2}=\mathrm{OCH}_{3} ; \mathrm{X}=\mathrm{Cl}$ 16: $\mathrm{R}_{1}=\mathrm{H} ; \mathrm{R}_{2}, \mathrm{R}_{3}, \mathrm{R}_{4}=\mathrm{OCH}_{3} ; \mathrm{X}=\mathrm{Br}$ 17: $\mathrm{R}_{1}, \mathrm{R}_{2}, \mathrm{R}_{3}=\mathrm{OCH}_{3} ; \mathrm{R}_{4}=\mathrm{H} ; \mathrm{X}=\mathrm{Br}$ 18: $R_{1}, R_{4}=H: R, R_{3}=O_{3} ; X=B r$ 19: $\mathrm{R}_{1}, \mathrm{R}_{2}=\mathrm{OCH}_{3} ; \mathrm{R}_{3}, \mathrm{R}_{4}=\mathrm{H} ; \mathrm{X}=\mathrm{Br}$ 20: $R_{1}, R_{4}=O_{C H} ; R_{2}, R_{3}=H ; X=B r$ 21: $R_{1}, R_{2}, R_{4}=H, R_{3}=\mathrm{OCH}_{3} ; X=\mathrm{Cl}$ 22: $\mathrm{R}_{1}, \mathrm{R}_{3}, \mathrm{R}_{4}=\mathrm{H} ; \mathrm{R}_{2}=\mathrm{OCH}_{3} ; \mathrm{X}=\mathrm{Cl}$ 15: $\mathrm{R}_{1}=\mathrm{OCH}_{3} ; \mathrm{R}_{2}, \mathrm{R}_{3}, \mathrm{R}_{4}=\mathrm{H} ; \mathrm{X}=\mathrm{Cl}$

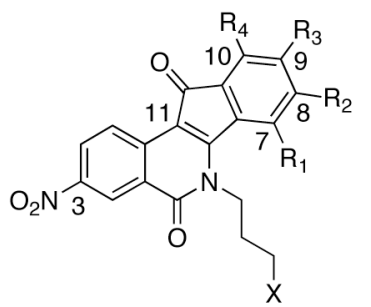

24: $\mathrm{R}_{1}, \mathrm{R}_{2}, \mathrm{R}_{3}=\mathrm{OCH}_{3} ; \mathrm{R}_{4}=\mathrm{H} ; \mathrm{X}=\mathrm{Br}$ 25: $\mathrm{R}_{1}, \mathrm{R}_{4}=\mathrm{H} ; \mathrm{R}_{2}, \mathrm{R}_{3}=\mathrm{OCH}_{3} ; \mathrm{X}=\mathrm{Br}$ 26: $\mathrm{R}_{1}, \mathrm{R}_{2}=\mathrm{OCH}_{3} ; \mathrm{R}_{3}, \mathrm{R}_{4}=\mathrm{H} ; \mathrm{X}=\mathrm{Br}$ 27: $\mathrm{R}_{1}, \mathrm{R}_{2}, \mathrm{R}_{4}=\mathrm{H}, \mathrm{R}_{3}=\mathrm{OCH}_{3} ; \mathrm{X}=\mathrm{Cl}$ 28: $\mathrm{R}_{1}=\mathrm{OCH}_{3} ; \mathrm{R}_{2}, \mathrm{R}_{3}, \mathrm{R}_{4}=\mathrm{H} ; \mathrm{X}=\mathrm{Cl}$

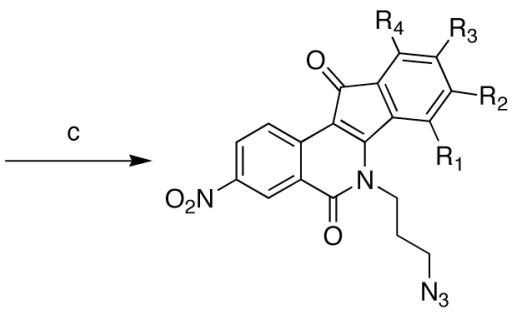

29: $\mathrm{R}_{1}, \mathrm{R}_{2}, \mathrm{R}_{3}=\mathrm{OCH}_{3} ; \mathrm{R}_{4}=\mathrm{H}$ 30: $R_{1}, R_{4}=H ; R_{2}, R_{3}=O_{3}$ 31: $\mathrm{R}_{1}, \mathrm{R}_{2}=\mathrm{OCH}_{3} ; \mathrm{R}_{3}, \mathrm{R}_{4}=\mathrm{H}$ 32: $R_{1}, R_{2}, R_{4}=H, R_{3}=\mathrm{OCH}_{3}$ 33: $\mathrm{R}_{1}=\mathrm{OCH}_{3} ; \mathrm{R}_{2}, \mathrm{R}_{3}, \mathrm{R}_{4}=\mathrm{H}$<smiles></smiles>

$\cdot \mathrm{HCl}$

34: $\mathrm{R}_{1}, \mathrm{R}_{2}, \mathrm{R}_{3}=\mathrm{OCH}_{3} ; \mathrm{R}_{4}=\mathrm{H}$ 35: $\mathrm{R}_{1}, \mathrm{R}_{4}=\mathrm{H} ; \mathrm{R}_{2}, \mathrm{R}_{3}=\mathrm{OCH}_{3}$ 36: $\mathrm{R}_{1}, \mathrm{R}_{2}=\mathrm{OCH}_{3} ; \mathrm{R}_{3}, \mathrm{R}_{4}=\mathrm{H}$ 37: $\mathrm{R}_{1}, \mathrm{R}_{2}, \mathrm{R}_{4}=\mathrm{H}, \mathrm{R}_{3}=\mathrm{OCH}_{3}$ 38: $\mathrm{R}_{1}=\mathrm{OCH}_{3} ; \mathrm{R}_{2}, \mathrm{R}_{3}, \mathrm{R}_{4}=\mathrm{H}$

\section{Scheme 1.}

Reagents and conditions: (a) $\mathrm{CHCl}_{3}$, $\mathrm{RT}$; (b) i. $\mathrm{SOCl}_{2}$, benzene, reflux; ii. $\mathrm{AlCl}_{3}$, nitrobenzene, $100{ }^{\circ} \mathrm{C}$; (c) $\mathrm{NaN}_{3}$, DMSO, $100{ }^{\circ} \mathrm{C}$; (d) i. $\mathrm{P}(\mathrm{OEt})_{3}$, benzene, reflux; ii. $3 \mathrm{M} \mathrm{HCl} /$ $\mathrm{MeOH}$, benzene, reflux. 
<smiles>[R3]c1cc([C@H]2[C@H](C(=O)O)c3ccc([N+](=O)[O-])cc3C(=O)N2CCCBr)c([R])c([R6])c1[R5]</smiles>

16: $\mathrm{R}_{1}=\mathrm{H} ; \mathrm{R}_{2}, \mathrm{R}_{3}, \mathrm{R}_{4}=\mathrm{OCH}_{3}$

18: $R_{1}, R_{4}=H ; R_{2}, R_{3}=O_{3}$

39: $\mathrm{R}_{1}=\mathrm{H} ; \mathrm{R}_{2}, \mathrm{R}_{3}, \mathrm{R}_{4}=\mathrm{OCH}_{3}$

40: $\mathrm{R}_{1}, \mathrm{R}_{4}=\mathrm{H} ; \mathrm{R}_{3}, \mathrm{R}_{3}=\mathrm{OCH}_{3}$<smiles>[R]c1c([R])c([R])c2c(c1[R])Cc1c(c3ccc([N+](=O)[O-])cc3c(=O)n1CCCN)C2=O</smiles>

41: $\mathrm{R}_{1}=\mathrm{H} ; \mathrm{R}_{2}, \mathrm{R}_{3}, \mathrm{R}_{4}=\mathrm{OCH}_{3}$ 30: $R_{1}, R_{4}=H ; R_{2}, R_{3}=O_{3}$<smiles>[R]c1c([R])c([R])c2c(c1[R])c(=O)c1ccc([N+](=O)[O-])cc1c(=O)n2CCCN</smiles>

42: $\mathrm{R}_{1}=\mathrm{H} ; \mathrm{R}_{2}, \mathrm{R}_{3}, \mathrm{R}_{4}=\mathrm{OCH}_{3}$ 35: $\mathrm{R}_{1}, \mathrm{R}_{4}=\mathrm{H} ; \mathrm{R}_{2}, \mathrm{R}_{3}=\mathrm{OCH}_{3}$

Scheme 2.

Reagents and conditions: (a) $\mathrm{P}_{2} \mathrm{O}_{5}, \mathrm{CHCl}_{3}$, reflux; (b) $\mathrm{NaN}_{3}$, DMSO, RT; (c) i. $\mathrm{P}(\mathrm{OEt})_{3}$, benzene, reflux; ii. $3 \mathrm{M} \mathrm{HCl} / \mathrm{MeOH}$, benzene, reflux. 


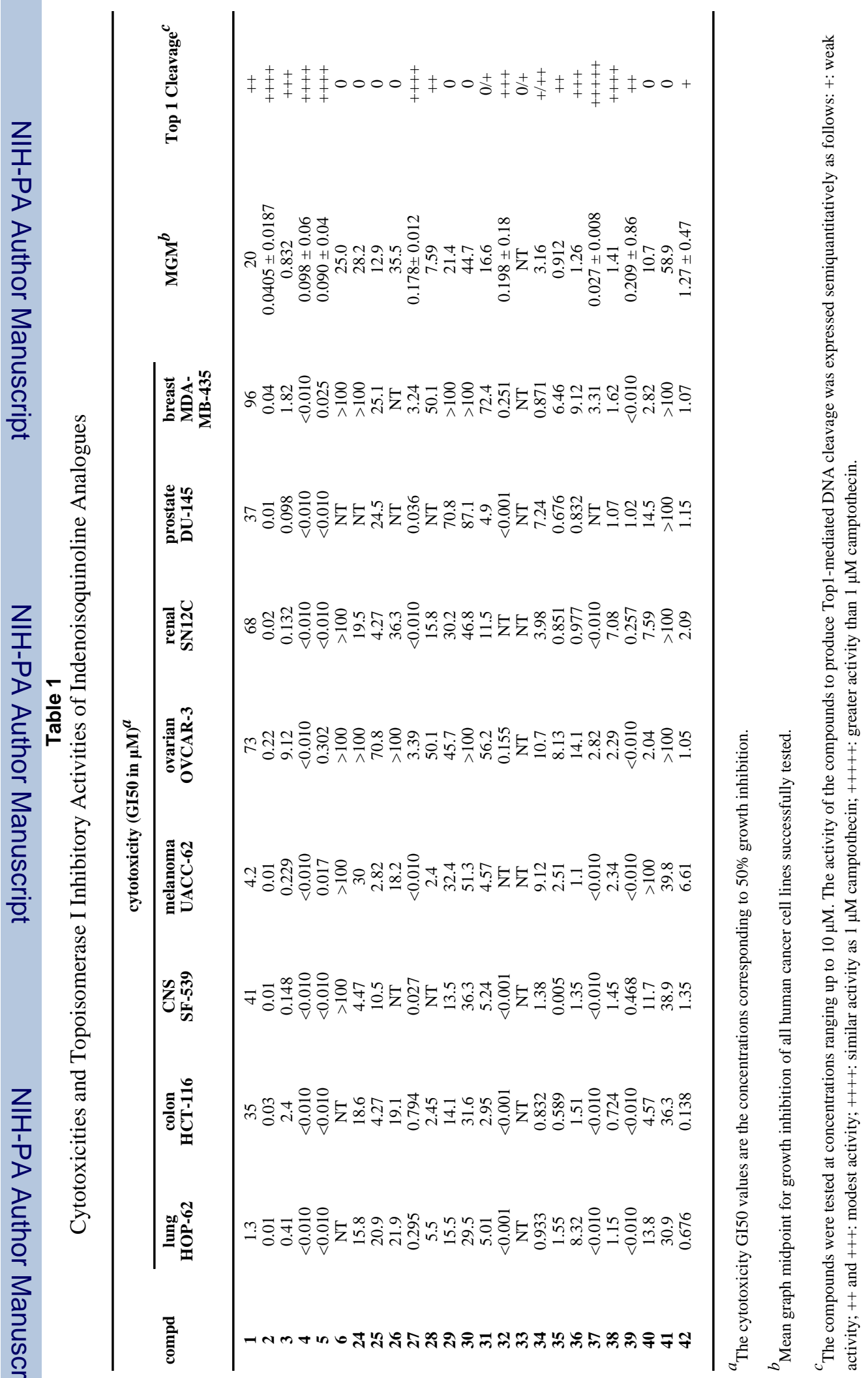

